\title{
EQUAL EDUCATIONAL OPPORTUNITY FOR CHILDREN WITH SPECIAL NEEDS: THE FEDERAL ROLE IN AUSTRALIA
}

\author{
Betsy LeVIN* \\ INTRODUCTION
}

Starting in the mid-1960's, the national governments in both the United States and Australia significantly increased their level of involvement in elementary and secondary education, despite the fact that in both systems there is no direct constitutional responsibility for education at the federal level. Among the primary concerns of both governments has been the enhancement of equal educational opportunity for children with special needs. Initiatives in this area have created tensions and strains in the federal systems of both nations. State education authorities (and, in the United States, local authorities as well) resent federal intrusion upon what has traditionally been their prerogative and seek more flexible guidelines and more state autonomy. On the other hand, interest groups representing special pupil populations (such as the poor, minorities, linguistic minorities, and the handicapped) press for tighter federal guidelines to ensure that federal funds are spent for the purposes specified and to ensure that those who have been excluded by educational institutions or given less than an equal opportunity are adequately protected.

There are many similarities between the United States and Australia that make such a comparison between the two countries useful. ${ }^{1}$ They are both

\footnotetext{
Copyright (C) 1985 by Law and Contemporary Problems

* Dean and Professor of Law, University of Colorado; LL.B. Yale University. The author wishes to acknowledge the very able and conscientious research assistance of James Scott Needham, a thirdyear law student at the University of Colorado School of Law. Special thanks are due to Dr. I.F.K. Birch, Head, Department of Education, University of Western Australia, both for providing the opportunity for undertaking the research on which this article is based and for sharing his insights on the topic.

1. When an occasion arose to explore the federal role in education in Australia and its constitutional underpinnings, it seemed to be an ideal opportunity to get some comparative perspective on the federal approach to providing equal educational opportunity for special pupil populations. I was invited to be a Visiting Fellow at the University of Western Australia, in Perth, in the summer of 1983. The all-too-brief time spent there gave me, at best, merely a superficial impression of the role that the Commonwealth government plays in education and issues of federalism in Australia. I met with officials from the Commonwealth Schools Commission, the Commonwealth Department of Education, State Education Departments of Western Australia (Perth) and New South Wales (Sydney), the Department of Education of the Australian Capital Territory (ACT), the Catholic Education Commission of New South Wales, and the Goldfield Region District of Western Australia. I also met
} 
modern, industrialized nations which developed from former British colonies. $^{2}$ Their language, laws, systems of government, political, economic, and social customs and traditions reflect their predominantly English origins.

The governmental systems of the two countries have much in common. They are both federations with written constitutions ${ }^{3}$ and judicial review. ${ }^{4}$ Both countries, prior to unification by federation, consisted of collections of self-governing Crown colonies. Each colony was independent of the others, sometimes very much so. ${ }^{5}$ Both countries adopted a political system that

with Justice Lionel Murphy of the High Court of Australia, several federal judges, a number of lawyers, and members of the education and law faculties at several universities; I visited several elementary and secondary schools and teachers. I am extremely grateful to all those who gave so generously of their time to try to enlighten me. The errors and misunderstandings that undoubtedly have crept into this article are my own-surely due, in part, to the sensory overload I experienced in the six short weeks I was in Australia.

Although I understand that some legislative or other changes in programs may have occurred during the past year, this article, written in Spring 1984, is based on information obtained during the summer of 1983 .

2. Australia may owe its existence to the United States. The establishment on the island continent of New South Wales as an English colony was precipitated by the successful struggle of the thirteen American colonies for independence, since Great Britain needed an alternative location to which to transport convicts.

3. A comparison of the language of the Australian and U.S. constitutions reveals striking similarities. Indeed, the U.S. Constitution was the model for the Australian Constitution, although the most obvious model for the federal union of a contiguous group of British colonies would seem to have been the Canadian Constitution. The Australians were concerned, however, with the dominant position assigned in the Canadian Constitution to the central government (in particular, the power of the federal government in Canada to veto provincial legislation). See J. La Nauze, The Making of the Australian Constitution 16-17 (1972).

At a conference on federation, held in Melbourne in 1891, a draft constitution was introduced, drawing heavily on the U.S. Constitution. However, it was "put by" (tabled) for six years. Id. at 87 . When the Constitutional Convention reassembled in Adelaide in 1897, various committees of the Convention worked from the chapters of the 1891 draft. Id. at 123 . The original 1891 draft had provided for the possibility of a system of "inferior" federal courts like that of the United States. These courts, together with the Supreme Court, would exercise the whole of federal jurisdiction. The committee, however, modified the 1891 draft to provide for the possibility of investing state courts with federal jurisdiction. Id. at 130-31.

The drafters also relied on American legal precedents. For example, as has been noted with regard to commerce:

[I]t was abundantly clear from American precedents that the general federal power to regulate trade and commerce with other countries and among the States amply covered the use of navigable rivers as highways for commerce. There was no need to name specific rivers, and indeed to do so would inevitably invite restrictive interpretation of the power.

Id. at 210 .

Even more striking than the parallels in language are the parallels in structure. In the Australian document, as in that of the United States, many national powers are specifically listed. Compare Austr. Const. \$51 with U.S. Const. art. I, \& 8. Residual powers remain with the states. Compare AUstL. Const. $\S 106-108$ with U.S. Const. amend. X. Although a few powers are exclusive grants to the Commonwealth, most are concurrent. The Australian supremacy clause provides that when State and Commonwealth laws conflict, those of the Commonwealth prevail. Compare AustL. Const. $\S 109$ with U.S. Const. art. VI, § 2.

However, the Australian Constitution contains no guarantees of individual liberties and rights comparable to those enshrined in the Bill of Rights and the fourteenth amendment to the U.S. Constitution. See infra text accompanying note 32 .

4. "[I]n our system the principle of Marbury $v$. Madison is accepted as axiomatic." Australian Communist Party v. Commonwealth (The Communist Party Case), 83 C.L.R. 1, 262 (Austl. 1951) (Fullager, J.).

5. In Australia, the colonial legislatures were considerably more independent in domestic matters than were the American colonies. 
would preserve most of the advantages and powers that had been enjoyed by the colony-states as separate entities, yet would also result in a unified nation. ${ }^{6}$ Within this federal structure, powers and responsibilities are divided between central (or federal) and state governments. ${ }^{7}$ Jurisdictional disputes and conflicts about authority are commonplace in both countries.

The two countries have many demographic similarities. Both are essentially urban, industrialized societies ${ }^{8}$ with densely populated cities and suburbs. Despite the concentration of population in the urban areas, however, both countries have recent rural origins and still have strong rural interests that play a more powerful role in economic, political and social life than the size of the rural populations appears to warrant. Moreover, because the countries are large and contain within their borders a number of different geographical regions, there are in both countries wide divergences in population density and cultural characteristics that may have substantial influence on educational policy.

The ethnic backgrounds of the two countries also are similar. In both the United States and Australia, there were indigenous people whose cultures and social structure fell victim to white settlers' prejudice and ignorance. The Australians have now recognized, as have the Americans, that addressing the problems these people currently face has a national priority. The difficult issue is how to preserve what remains of their cultures while allowing them to enter with full dignity into the mainstream of society.

Despite their predominantly English origins, both countries are comprised of immigrant stock from many European cultures. Australia, however, had a much more recent European immigration and now a very heavy Asian immigration. In the United States, European immigration waves not only occurred somewhat earlier than in Australia, but also from a greater variety of European countries. Both countries until recently espoused the melting-pot philosophy and adopted. policies with respect to immigrants which attempted to discourage or submerge the subcultures of their citizens in order to promote national unity. ${ }^{9}$ The educational system was the principal means for integrating immigrants into the British culture. ${ }^{10}$ Both countries have only recently begun to question the validity of assimilationist policies and to explore the value of cultural pluralism, and the role that the educational system should play.

In the field of education policy, there are also some common aspects. Both countries have highly developed educational systems which extend from

6. See P. Hay \& R. Rotunda, The United States Federal System 1-25 (1982); J. McMillan, G. Evans, \& H. Storey, Australia's Constitution: Time for Change? 39-48 (1983).

7. See generally P. HAY \& R. RotUndA, supra note 6; Hutley, The Legal Traditions of Australia as Contrasted with those of the United States, 55 AustL. L.J. 63, 70 (1983). In the case of the United States, major responsibilities and powers are also delegated by the states to local authorities.

8. Australia, of course, is not nearly as industrialized as the United States.

9. See generally D. Tyack, Turning Points in American Educational History 123-24, 228-63 (1967).

10. Id. 
preschool through higher education. In both countries, although public education constitutes the major sector, private schools are an important part of the educational pattern. ${ }^{11}$ Indeed, there is some evidence in both countries of an upward trend in private school enrollments.

Both countries divide responsibility for education between state and federal governments, as a result of constitutional provisions and other legal and administrative requirements. Both are attempting to.implement the goal of equality of educational opportunity while also seeking to ensure freedom of choice, the attainment of appropriate standards, and the promotion of social cohesion. In seeking to achieve these goals, the two countries must deal with federal-state political and fiscal relationships, sharply declining birthrates, large ethnic minority groups, and the fact that education no longer has as high a priority as other public needs. ${ }^{12}$

Finally, the pattern of intervention in education on the part of the federal government has been similar in the two countries. ${ }^{13}$ Both countries relatively recently increased the federal role in education even though the states have the constitutional responsibility for education. For the first half of the twentieth century, there were only sporadic, incremental federal aid-to-education programs in both countries, and there were no federal civil rights mandates in either country. Sputnik was the impetus in Australia as well as in the United States for the first major aid-to-education program. Sputnik triggered the National Defense Education Act of 1958 in the United States. ${ }^{14}$ It took Australia a little while longer, but in 1964 the Science Laboratories Act, which was to provide federal funds for improving science education and training (as did the NDEA), was passed. ${ }^{15}$

In 1965, the United States enacted a multibillion dollar act, the Elementary and Secondary Education Act, ${ }^{16}$ which along with other measures provided funds for compensatory education for disadvantaged children ${ }^{17}$ and for school libraries. ${ }^{18}$ Similarly, in Australia, a significant federal aid-to-education act, the States Grants (Schools) Act 1973, provided funds for disadvantaged children and for school libraries along with other specific purpose

11. A higher proportion of students go to private schools in Australia than in the United States and "nongovernment" schools (both religious and secular) receive public funds.

12. See Levin, Equal Educational Opportunity for Special Pupil Populations and the Federal Role, $85 \mathrm{~W}$. Va. L. Rev. 159, 183 (1983). But see Nat'l Comm'n on Excellence, A Nation at Risk: The ImperaTIVE FOR EDUCATIONAL REFORM (1983).

13. When the Labor government came to power in 1972 in Australia, education was split off from the Department of Science and Education and a new Department of Education was created. Interview with Kim Beazley, former Minister of Education (June 1980); Interview with Kenneth Jones (June 1980). Similarly, the U.S. Department of Education was separated from the Department of Health, Education \& Welfare (now the Department of Health and Human Services) in 1979. See Department of Education Organization Act of 1979, Pub. L. No. 96-88, 93 Stat. 668 (codified as amended at 20 U.S.C. $\S \S 340 \mathrm{l}-3510(1982)$ ).

14. Pub. L. 85-864, 72 Stat. 1580 (1958) (codified as amended at 20 U.S.C. $\$ \$ 401-589$ (1982)).

15. States Grants (Science Laboratories and Technical Training) Act 1964, 1964 Austl. Acts 246.

16. Pub. L. No. 89-10, 79 Stat. 27 (1965) (codified as amended in scattered sections of 20 U.S.C.).

17. Id. tit. I, 79 Stat. at 27-36 (codified as amended at 20 U.S.C. $\$ \S 2701-2854$ (1982))

18. Id. tit. II, 79 Stat. at $36-39$ (codified as amended at 20 U.S.C. $\S \S 2881-2887$ (1982)). 
grants. ${ }^{19}$

Despite these similarities, there are also significant differences between Australia and the United States and these differences must be kept in mind in comparing the federal role in education in the two countries. They differ vastly in the size of their population - Australia's population of fourteen million is in stark contrast to the $\mathbf{2 3 6}$ million of the United States - and in number of political divisions - Australia has only six states ${ }^{20}$ and two territories. ${ }^{21}$ Moreover, in Australia, a local government system with only limited powers evolved and thus there is no locally organized educational system. The original settlements were at the coastal ports, and most of the population remains along the coast today. The tremendous number of local authorities and special districts, each with its own taxing authority, that are found in the United States-school districts, fire districts, water districts, and mosquito abatement districts, for example, as well as counties, cities, and townshipsdoes not exist in Australia.

The population in the United States is not only much larger, it is also much more diverse. ${ }^{22}$ Thus the United States has both greater complexity in its governmental structure and more diverse special interests. This greater diversity and complexity has, in large part, been responsible for the proliferation of categorical programs at both state and federal levels, in contrast to what has occurred in Australia.

Both Australia and the United States have written constitutions. Despite similarities both in documentary language and in the structure of government set up in these constitutions, ${ }^{23}$ however, there are some fundamental differ-

19. States Grants (Schools) Act 1973, 1973 Austl. Acts 1407. Australia's act went beyond categorical funding, however, and included funds for general operating and capital expenses, for both public and private schools. See infra text accompanying notes 96-97.

20. An act of the British Parliament brought the Commonwealth of Australia into being on January 1, 1901, as a federation of six self-governing British colonies: New South Wales (capital: Sydney), Victoria (capital: Melbourne), South Australia (capital: Adelaide), Queensland (capital: Brisbane), Tasmania (capital: Hobart), and Western Australia (capital: Perth). Commonwealth of Australia Constitution Act, 1900, 63 \& 64 Vict., ch. 12.

21. The Northern Territory remains a territory administered by the Commonwealth. Australian Capital Territory (ACT) is the area in which the Australian capital, Canberra, is located. The Australian Constitution provides that " $[\mathrm{t}]$ he seat of Government of the Commonwealth shall be determined by the Parliament .... Austl. Const. $\S 125$. In 1908 a 911 square mile area now known as the Australian Capital Territory was chosen for this purpose; it was transferred to the Commonwealth by the State of New South Wales in 1911. Administered by the federal government, the Territory contains large areas of land set aside for parks, natural reserves, and other public purposes, as well as Canberra, the national capital.

22. The lack of racial and ethnic diversity has its origins in the "white Australia" policy. With the exception of its small aboriginal population, Australia at the time of federation was more than 98 percent white. One of the first statutes enacted by the Parliament of the new Commonwealth, the Immigration Restriction Act 1901, 1901-2 Austl. Acts 252 (repealed 1958), helped ensure that Australia remained so. Section 3(a) of the Act excluded "[a]ny person who when asked to do so by an officer fails to write out at dictation and sign in the presence of the officer a passage of fifty words in length in an [sic] European language directed by the officer." This test remained in effect until 1958. It has been pointed out that no unwanted immigrant could satisfy the dictation test, as "all an officer had to do was select a language that the applicant did not know." W. Murphy \& J. Tanenhaus, Comparative Constitutional Law: Cases and Commentaries 69 (1977). This test was used to keep out southern Europeans as well as Asians, Africans, and Middle Easterners. Id. .

23. See supra text accompanying notes 3-4. 
ences. The Australian Constitution contains no such guarantees of fundamental rights and individual freedoms as appear in the U.S. Constitution's Bill of Rights and fourteenth amendment. Moreover, the structure of government established in the Australian Constitution is that of a parliamentary system. The possibility of an independently elected executive and the marked separation of the executive and the legislative branches found in the American system are absent from the Australian Constitution, which requires that all Commonwealth ministers be elected members of the Senate or House of Representatives. ${ }^{24}$

There are a number of important differences between the two legal systems which may be explained in part by the physical differences between the two countries and in part by the way in which the two countries gained independence. The United States had seemingly limitless expanses of rich, arable land and inexhaustible supplies of valuable natural resources. On the other hand, "[i]n Australia, the law bears the imprint of the limitless expanse of the land, but also of the poverty of the soil, the arid climate, and the absence of resources except minerals." 25 Although the country (an island continent actually) is about the size of the United States, excluding Alaska, it is "the driest, flattest and most barren land of comparable size on earth." 26 The population was sparse prior to federation and remains so today. The sparseness of the population meant that there were no local institutions, and that governance - under one system of laws - was centralized at the state level. ${ }^{27}$

Moreover, Australia is a country that "obtained the advantages of independence without having to fight for it."28 Its isolation meant that there was no danger of external enemies, and the Aboriginal population presented no serious obstacle to white settlers. There was no necessity to formulate an ideology to rally forces, as was needed in the United States to fight Great Britain and later to fight for the preservation of the Union. Thus, the United States appears to have more of an "ideological" constitution and an "ideological" legal system than is evident in Australia. ${ }^{29}$

For this reason, one of the major differences between the two countries lies in the role that the constitution plays. Although the justices of the High Court of Australia from time to time emphasize that the document they are construing is a constitution, ${ }^{30}$ it has also been said that they construe the con-

24. Austl. Const. § 64 .

25. Hutley, supra note 7 , at 63 .

26. Id.

27. See id. at 63-64.

28. Id. at 65 .

29. See id. The Commonwealth that emerged in 1901, after ten years of consultation and hard bargaining, "was no Phoenix arising from the ashes of revolution or disaster; it was begotten of no great surge of political idealism; it was in fact the child of as hard-headed a mariage de convenance as was ever raised in the salons of France." Anderson, The States and Relations with the Commonwealth, in Essays on the Australian Constitution 93 (R. Else-Mitchell 2d ed. 1961).

30. "[I]t is a Constitution we are interpreting, an instrument of government meant to endure and conferring powers expressed in general propositions wide enough to be capable of flexible application to changing circumstances." Australian Nat'l Airways Proprietary, Ltd. v. Commonwealth, 71 C.L.R. 29, 81 (Austl. 1945) (Dixon, J.). 
stitution exactly as they would a will. ${ }^{31}$ Treating the constitution as an ordinary British statute means that it has not acquired the sacred aura which surrounds the American Constitution; it does not enunciate any moral principles. Partly for this reason, the Australian Constitution contains no guarantee of rights analogous to those articulated in the U.S. Bill of Rights. ${ }^{32}$

Another fundamental difference between Australia and the United States is the relatively greater homogeneity of Australian law. In Australia the states, when they entered the Federation, had already adopted English law, while some states in the United States ${ }^{33}$ had a different system of law in existence when they became part of the Union. One factor lessening the diversity of law among the Australian states is the dominance of English traditions in the training of lawyers and organization of the legal profession. Another factor is the possibility of appeal to the Privy Council of Great Britain from Australian state courts in state matters; until very recently, appeals could also be taken

31. Hutley, supra note 7, at 65; see also W. Murphy \& J. TANEnhaus, supra note 22, at 77-78.

32. This omission is the result of a conscious decision by the framers of the Australian Constitution, who, in drafting their own document, had before them the American Constitution but deliberately excised substantially all of the Bill of Rights. See Hutley, supra note 7, at 65. An Australian Chief Justice, Sir Owen Dixon, explained to an American audience that "this silence . . . reflected the firm confidence of the framers in the traditions and institutions of Parliamentary democracy." J. LA NAUZE, supra note 3, at 227. "Why, asked the Australian democrats, should doubt be thrown on the wisdom and safety of entrusting to the chosen representatives of the people sitting either in the federal Parliament or in the State Parliaments all legislative power, substantially without fetter or restriction?" O. Dixon, Two Constitutions Compared, in Jesting Pilate 100, 102 (1965), quoted in J. LA NAUZE, supra note 3, at 227. This explanation may "account for the absence of such American guarantees as those against the quartering of soldiers in private houses in time of peace, and against unusual and cruel punishments: these and other such relics of the eighteenth century were (as it seemed in the 1890s) forever obsolete." J. LA NAUzE, supra note 3, at 227. It does not, however, account for the absence of some of the other American guarantees such as equal protection.

The 1891 draft had included the following clause, adopted without debate: "[a] State shall not make or enforce any law abridging any privileges of citizens of other States, nor shall a State deny to any person within its jurisdiction the equal protections of the laws." Id. at 230. This was clearly based on the fourteenth amendment to the U.S. Constitution, though it omitted "due process of law"; it also resembled art. IV, section 2 "in referring to citizens of States rather than of the federation." In the end, however, proposals to include such provisions were defeated. Id. In part, the proposals' defeat resulted from an opponent pointing out that the equivalent phrases in the U.S. Constitution had been provided mainly to protect emancipated Negroes after the Civil War, and could be very difficult to interpret. Later in the debate, the issue was raised again by pointing to lower court decisions in the United States which were by no means confined to those involving Negroes. A debate ensued on the meaning and definition of "citizens of the Commonwealth" and finally, section 117 was adopted, reflecting only the privileges and immunities clauses of the U.S. Constitution. See U.S. Const. art. IV, § 2; id. amend. XIV, §2. Section 117 has had no discernible constitutional significance in the ensuing years. J. LA NAUZE, supra note 3, at 229.

There were other, less generous, reasons for rejecting references to "equal protection." One was a concern about the validity of state legislation that discriminated against nonwhites. For example, the State of Victoria had factory laws that discriminated against the Chinese and the State of Western Australia had laws prohibiting Asian or African aliens from mining gold. These examples were raised by a number of delegates and soon other apprehensions about interference with state legislation began to appear. One of the delegates to the Constitutional Convention has been quoted as follows: "[W]e want, as I understand it, to prohibit any discrimination which is based upon false principle . . . we want a discrimination based on colour." Statement of Henry Bournes Higgins, quoted in Evans, The Most Dangerous Branch? The High Court and the Constitution in a Changing Society, in Australian Lawyers and Social Change 13, 17 (D. Hambly \& J. Goldring eds. 1976).

33. E.g., California, Louisiana, and Texas. 
from the High Court to the Privy Council. ${ }^{34}$ One of the objectives of the Privy Council was to promote the uniformity of law throughout the British Empire. The Privy Council said in Trimble v. Hill, ${ }^{35}$ an 1879 case on appeal from the Supreme Court of New South Wales, that "it is of the utmost importance that in all parts of the empire where English law prevails, the interpretation of that law by the Courts should be as nearly as possible the same." 36 The High Court of Australia accepted this principle and, on a number of occasions, reversed its own previous decisions to bring them into line with decisions of the Privy Council. ${ }^{37}$

Also affecting the lack of diversity in Australian law is the fact that the High Court is the final court of appeal for all state courts, even on state matters, ${ }^{38}$ as well as for the new system of federal courts. ${ }^{39}$ The High Court is therefore the final court of appeal on all legal questions in Australia, subject only to the remnants of power still vested in the Privy Council. Thus there is no limit on the jurisdiction of the High Court equivalent to the limitations imposed on the U.S. Supreme Court by article III of the U.S. Constitution. ${ }^{40}$

34. The Privy Council (Appeals from the High Court) Act 1975, 1975 Austl. Acts 225, abolished all appeals from the High Court.

35. 5 App. Cas. 342 (P.C. 1879).

36. Id. at 345 .

37. See Hutley, supra note 7 , at 68 (and cases cited therein).

38. Although the section of the Australian Constitution dealing with judicial power is modeled after article III of the U.S. Constitution, there are considerable differences. Section 71 of the Australian Constitution provides: "The judicial power of the Commonwealth shall be vested in a Federal Supreme Court, to be called the High Court of Australia, and in such other federal courts as the Parliament creates, and in such other courts as it invests with federal jurisdiction." Section 77 (iii) authorizes Parliament to make laws "[i]nvesting any court of a State with federal jurisdiction." Thus, rather than creating a comprehensive system of federal courts, as in the United States, the Judiciary Act 1903 established only one federal tribunal, the High Court. Judiciary Art 1903, § 4, 1903 Austl. Acts 8, 9 (amended 1976). Sweeping federal jurisdiction was then granted to the state court systems. With the exception of the specialized federal tribunals, established in 1976, see infra note 39 , this situation continues today.

39. Judiciary Act 1903, 1903 Austl. Acts 8, as amended by Judiciary Amendment Act 1976, 1976 Austl. Acts 1378. The Federal Court of Australia was established by the Federal Court of Australia Act 1976, 1976 Austl. Acts 1323. This Act confers original jurisdiction in "matters arising under laws made by Parliament." Id. $\$ 19(1), 1976$ Austl. Acts at 1330. The Industrial Division of the Federal Court handles labor questions such as conciliation and arbitration, while the General Division of the Federal Court handles matters involving bankruptcy, copyright, administrative law, consumer protection, restrictive trade practices, and price justification (i.e., antitrust cases). There is also a separate federal Family Court, created in 1975 and given exclusive jurisdiction to handle cases arising under the Commonwealth Family Law Act, with a direct appeal by special leave to the High Court. The Federal Court has appellate jurisdiction in three kinds of cases: (1) appeals from the judgments, decrees, or orders and sentences of a single federal judge, Federal Court of Australia Act 1976, $\$ 24(1)$ (a), 1976 Austl. Acts at 1331; (2) general appeals, civil and criminal, from a supreme court of a territory, id. $\S 24(1)($ b), 1976 Austl. Acts at 1331; and (3) appeals, pursuant to a specific provision of an act of Parliament, from a single-judge state supreme court exercising federal jurisdiction, id. $\$ 24(1)(c), 1976$ Austl. Acts at 1331. Crawford, The New Structure of Australian Courts, 6 Adelaide L. REv. 201 (1978). See generally Lane, The New Federal Jurisdiction, 54 AusTL. L.J. 11 (1980).

40. The High Court's procedures are somewhat different from those of the U.S. Supreme Court. The justices do not normally sit en banc, but in panels which, in cases arising under the Court's appellate jurisdiction, must consist of two or more justices. (In cases coming to the Court under its original jurisdiction, a single justice sits as trial judge. His findings are then referred to the full court-which may be as few as two justices-which then proceeds as in other appeals.) Normally, three members hear routine private-law appeals, but five to seven members sit in more important litigation and, when there is a constitutional case of significance, the court tries to sit en banc. Inter- 
Finally, and of most importance in understanding the differences between the two countries with respect to the federal role in education, the Australian federal constitution addresses itself much more to the mechanics of government than to checks and balances at the federal level. Rather than a concern for the balance of power among the three branches of the federal government, the emphasis in Australia is on an appropriate balance between the Commonwealth and the states. ${ }^{41}$

\section{II}

\section{The Present Federal Role in Education in Australia}

\section{A. The Historical Role of the Commonwealth in Education}

In Australia, the states existed before the establishment of the Commonwealth in 1901,42 and thus the state constitutions predate the Commonwealth constitution. The state constitutions empower their legislatures to provide for "peace, order, and good government," 43 thus giving the states authority

view with Mr. Justice Lionel Murphy (July 8, 1983) (memorandum on file with the author). Since Section 23(i) of the Judiciary Act requires at least three justices to concur in a decision (but not an opinion) settling a question involving the Commonwealth's constitutional powers, at least five justices must participate in constitutional cases. See Judiciary Act 1903, § 23(i), 1903 Austl. Acts 8, 12 (amended 1976).

Cases are presented almost entirely through oral argument; written briefs are not submitted. Oral argument is unlimited; for example, Commonwealth v. Tasmania (The Tasmanian Dam Case), 46 Austl. L.R. 625 (1983) (discussed infra, text accompanying notes 161-206) took 8 days to argue. Id. at 625; Interview with Mr. Justice Murphy, supra. The Communist Party Case, Australian Communist Party v. Commonwealth, 83 C.L.R. 1 (Austl. 1951), took 24 days. Even routine cases take half a day. Determining the ratio decidendi for any particular judgment is extremely difficult, since each justice generally writes his own separate opinion. According to Justice Murphy, the justices did not meet to vote on the cases. Although each justice writes his own opinion, they do, of course, see copies of their colleagues' opinions before they are released to the public. However, the justices sometimes may not know the outcome of the case until the pro and con opinions are counted up. Interview with Mr. Justice Murphy, supra.

In accordance with section 35 of the Judiciary Act 1903, as amended by Judiciary Amendment Act 1976,1976 Austl. Acts 1378, 1379-80, there is an appeal as of right from state supreme courts only with respect to judgments of a full state supreme court involving at least $\$ 20,000$ or a matter of constitutional interpretation. All other appeals, including those from a single-judge state supreme court, require special leave. Special leave is granted only under "exceptional circumstances." $C f$. Mason, Where Now?, 49 Austl. L.J. 570, 576 (1975). In addition, cases can be removed to the High Court in two circumstances: (l) in constitutional cases, before judgment by a lower appellate court, on application of a state or Commonwealth Attorney-General or, at the discretion of the High Court, on application and a showing of special cause by a party, Judiciary Act $1903, \S 40$ (I), as amended by Judiciary Amendment Act 1976, 1976 Austl. Acts 1378, 1380; or (2) in nonconstitutional cases involving the exercise of federal jurisdiction (identified in Sections 75 and 76 of the constitution), id. $\$ 40(2)(\mathrm{b})$, as amended by Judiciary Amendment Act 1976, 1976 Austl. Acts at 1381 . In nonconstitutional cases, removal is always a matter for High Court discretion and requires the consent of all parties. Id. $\S 40(4)$, as amended by Judiciary Amendment Act 1976, 1976 Austl. Acts at 1381.

41. The federal system in Australia, like that in the United States, is a limited government, having only those powers that are specifically enumerated. Section 107 of the Australian Constitution is similar to the U.S. Constitution's tenth amendment, differing, however, in its use of the words "unless. . . exclusively vested in the Parliament of the Commonwealth or withdrawn from the Parliament of the State." Austr. Const. $\$ 107$ (emphasis added).

42. The last state to be established was Western Australia in 1890.

43. See, e.g., N.S.W. Const. $\$ 5$ (enacted by Constitution Act 1902, 2 N.S.W. Pub. Acts 340,342 (1938)). 
over all social services. Relying on such provisions, the states have enacted public instruction acts. ${ }^{44}$ Like the U.S. Constitution, the Australian Constitution contains no education provision. Since section 106 of the Australian Constitution saves the states' constitutions at the time of federation, ${ }^{45}$ and sections 107 and 108 save the laws and powers of the state governments, ${ }^{46}$ education appears to have been a matter constitutionally left to the states.

Educational policy is still determined primarily by the states, though the delegation of authority within each state differs. The determination of school policy and authority to disburse funds may be formally or legally granted to the State Minister of Education, the Director-General, ${ }^{47}$ or the Governor. While there are also various national committees and commissions with differing roles, virtually all school policy is determined at the state level. There is no counterpart to the local education agencies or school boards found in the United States ${ }^{48}$ nor, at the other end of the spectrum, was there until recently any significant effort on the part of the Commonwealth to exert influence over educational policy.

One such attempted exercise of power by the Commonwealth government was based on the defense power, ${ }^{49}$ resulting in a High Court decision declaring that the states had responsibility for education in the Australian federal system..$^{50}$ In that case, an applicant had met all the requirements for university matriculation and admission to either the faculty of medicine or the faculty of dentistry. The plaintiff's application for admission was denied pur-

44. See, e.g., Public Instruction Act of 1880, 9 N.S.W. Pub. Acts 390 (1957) (amended 1979); Education Act 1928-1981, 19 Geo. 5, no. xxxiii, 5 W. Austl. RePr. ACTs 1 (1982).

45. "The Constitution of each State of the Commonwealth shall, subject to this Constitution, continue as at the establishment of the Commonwealth, or as at the admission or establishment of the State, as the case may be, until altered in accordance with the Constitution of the State." AustL. Const. $\$ 106$.

46. Every power of the Parliament of a Colony which has become or becomes a State, shall, unless it is by this Constitution exclusively vested in the Parliament of the Commonwealth or withdrawn from the Parliament of the State, continue as at the establishment of the Commonwealth, or as at the admission or establishment of the State, as the case may be.

Austl. Const. $\$ 107$.

Every law in force in a Colony which has become or becomes a State, and relating to any matter within the powers of the Parliament of the Commonwealth, shall, subject to this Constitution, continue in force in the State; and, until provision is made in that behalf by the Parliament of the Commonwealth, the Parliament of the State shall have such powers of alteration and of repeal in respect of any such law as the Parliament of the Colony had until the Colony became a State. Austl. Const. $\S 108$.

47. The Director-General is the permanent head of the state education department. The position is equivalent to that of a state commissioner or superintendent of education in the United States, although it is never an elected position. It is different, however, in that the state Minister of Education establishes policy, and the Director-General implements it - although in many cases, a Director-General is quite influential in the development of major educational policy changes. Educational policies are approved by the Minister but often shaped by the Director-General. Interview with Dr. Robert Vickery, Director-General of the Department of Education of Western Australia (July 5,1983 ) (memorandum on file with the author).

48. Victoria has recently established local school boards or councils that are elected. However, there is no local responsibility for revenue raising or for the hiring and promotion of teachers. Interview with Dr. Robert Vickery, Director-General of the Department of Education of Western Australia (July 12, 1983) (memorandum on file with author).

49. Austr. Const. §51(vi).

50. The King v. University of Sydney, 67 C.L.R. 95 (Austl. 1943). 
suant to national security regulations which gave power to the Commonwealth to "regulate, restrict or enlarge the number of students who may be enrolled in any faculty or course of study at that University." 51 The regulations were promulgated under the authority of the National Security Act which provided that appropriate regulations could be enacted "for securing the public safety and the defense of the Commonwealth" or "for prescribing all matters which are necessary or convenient to be prescribed, for the effectual prosecution" of the war. ${ }^{52}$ A quota had been established, and the seats had already been filled when the plaintiff applied. A majority of the High Court found the regulation to be an invalid exercise of Commonwealth power, related not to defense but to education, which the Court said was a function of the states.

In 1946, the Commonwealth Constitution was amended to permit the Commonwealth Parliament "to make laws . . . with respect to . . . benefits to students." 53 This provision gives the federal government some authority over education; however, the policy has still been to leave primary authority to the states.

One major difference between the United States and Australia, historically, has been the way in which education is financed. Although the Australian states play the principal role in policy setting and decisionmaking in the Australian schools, the Commonwealth has the primary powers of revenue raising. This revenue is partially directed back to the states, with discretion in spending left to the states.

Based on section 51 (ii) (the taxing power) and the section 96 power to

51. Regulation I6(2)(a), National Security (Universities Commission) Regulations, 1943 Austl. Stat. R. 28 , at $773,777$.

52. National Security Act 1939-40, § 5(1), 1940 Austl. Acts 78, 79 (repealed 1950).

53. Austl. Const. $\$ 51$ (xxiiiA). After the High Court's decision in the Pharmaceutical Benefits Case, Attorney-General for Victoria ex rel. Dale v. Commonwealth, 71 C.L.R. 237 (Austl. 1945), which significantly restricted the scope of the Commonwealth's power under section 81 to appropriate funds "for the purpose of the Commonwealth," the constitutional validity of all direct federal spending programs not authorized by a particular fount of Commonwealth legislative power was in question. Among the statutes thought questionable in whole or in part under the Pharmaceutical Benefits decision was the Education Act 1945, 1945 Austl. Acts 423 (intended "to establish a Commonwealth Office of Education and a Universities Commission, to provide for [schooling for veterans and financial aid to university students], and for other purposes"). The Constitution Alteration (Social Services) Act 1946, 1946 Austl. Acts 273, introduced to guarantee the validity of future federal welfare programs and to enable the Commonwealth to administer them, resulted in approval of section 51 (xxiiiA) by national referendum in 1946 and subsequent amendment of the constitution. See Sackville, Social Welfare in Australia: The Constitutional Framework, 5 FED. L. REv. 248, 256-57 (1973).

Federal Council of the British Medical Ass'n in Australia v. Commonwealth (The B.M.A. Case), 79 C.L.R. 201 (Austl. 1949) is the principal case interpreting section 51 (xxiii). In that case, the word "benefits" was given an expansive reading, to cover "provisions made to meet needs arising from special conditions with a recognized incidence in communities or from particular situations or pursuits such as that of a student, whether the provision takes the form of money payments or the supply of things or services." The B.M.A. Case, 79 C.L.R. at 260 (Dixon, J.). The B.M.A. decision indicated that the Commonwealth, in providing benefits, could impose whatever conditions it chose, and that the section 51(xxiiiA) power is "limited to the provision of the specified benefits by the Commonwealth itself," Sackville, supra at 260 (emphasis in original), and does not extend to legislation dealing with benefits provided, for example, by the states, "public bodies," and trading corporations. Id. 
make conditional grants, the Uniform Tax Scheme was introduced by the Commonwealth in 1942. Up until that time, both the Commonwealth and the states had taxed income, but there were significant variations among the states in tax structure and rates. The Uniform Tax Scheme ${ }^{54}$ altered this arrangement. ${ }^{55} \mathrm{~A}$ Commonwealth income tax was levied at a rate that would yield the same amount as that previously raised by the Commonwealth and the states combined; taxpayers were required to pay the Commonwealth income tax before any state income tax. If a state refrained from imposing a state income tax, it would receive from the Commonwealth an annual amount equal to that which it had previously collected in income tax. If a state levied any income tax at all, it would not get any portion of the Commonwealth's income tax revenue.

Financial assistance was thus granted to a state on condition that it abstain from exercising its own power to tax income. The effect was to force the states to cede their power to tax income to the federal government. In effect, Australia developed an extensive revenue-sharing program that has remained in existence ever since. ${ }^{56}$ "The proportion of total tax revenue collected by the Commonwealth is about 80 per cent," ${ }_{57}$ and it distributes about 30 per-

54. The Uniform Tax Scheme was based on four statutes. States Grants (Income Tax Reimbursement) Act 1942, 1942 Austl. Acts 46 (repealed 1946); Income Tax (War-Time Arrangements) Act 1942, 1942 Austl. Acts 48; Income Tax Assessment Act 1942, 1942 Austl. Acts 52 (amended 1973); Income Tax Act 1942, 1942 Austl. Acts 64.

55. See J. McMillan, G. Evans, \& H. Storey, supra note 6, at 108-09.

56. Although the scheme was a wartime measure, it has been continued to the present day. The states challenged its validity twice. In the principal case, South Australia v. Commonwealth, 65 C.L.R. 373 (First Uniform Tax Case) (Austl. 1942), a majority of the High Court upheld the Uniform Tax Scheme. The states had argued that sections 106 and 107 of the constitution prohibited either the Commonwealth or the states from usurping or undermining the functions or constitution of the other. Since taxation is an essential sovereign function, they argued, and principles of federalism require limiting the scope of Commonwealth powers that are exercised in derogation of such functions, the scheme was unconstitutional. A majority of the High Court found that since the scheme neither repealed state tax legislation nor required or compelled a state to abandon its taxing activities, but merely offered an inducement not to exercise power conceded to continue to exist, it was constitutional. Chief Justice Latham noted that the fact that in reality the states could not refuse to take the Commonwealth grants and thus were forced to give up their taxing power was not dispositive of the constitutional issue: "temptation is not compulsion." 65 C.L.R. at 417. Chief Justice Latham quotes from Justice Cardozo's majority opinion in Steward Machine Co. v. Davis, 30l U.S. $548,589-90$ (1936): "Every rebate . . . is in some measure a temptation. But to hold that motive or temptation is equivalent to coercion is to plunge the law in endless difficulties." South Australia v. Commonwealth, 65 C.L.R. at 418. The interpretation of sections 106 and 107 appears to be like that of the tenth amendment to the U.S. Constitution, in that these sections merely make clear that the Commonwealth is a government of limited powers. These sections do not limit or restrict those powers (such as taxation) granted to the Commonwealth.

The states challenged the validity of the Uniform Tax Scheme again in 1957 . Victoria v. Commonwealth, 99 C.L.R. 575 (Second Uniform Tax Case) (Austl. 1957). In response to this challenge, the High Court ruled invalid the priority given to the Commonwealth income tax, but the remaining elements of the scheme were upheld and those elements provided a sufficient basis for the Commonwealth to retain supremacy in the area of income tax. See J. McMillan, G. Evans \& H. Storey, supra note 6, at 109. The states had also sought to invalidate the portion of the Uniform Tax Scheme which, enacted pursuant to section 96, provided for financial assistance to those states that did not collect state income tax. All members of the High Court concurred in giving section 96 the widest possible scope: the Commonwealth can grant financial assistance to any state or to all and on whatever terms or conditions it sees fit. 99 C.L.R. at 575.

57. J. McMillan, G. Evans \& H. Storey, supra note 6, at 109 . In effect, the States' capacity to 
cent of these revenues to the states, principally through tax reimbursement grants but also using special equalization grants, ${ }^{58}$ specific purpose grants, and miscellaneous grants. The 30 percent distributed to the states constitutes about two-thirds of the states' total revenue. ${ }^{59}$

Thus, funds for education are substantially derived from consolidated revenues which are dispersed to the states as Parliament thinks "fit." 60 The Commonwealth government provides financial assistance grants ${ }^{61}$ to the states in a lump sum (as untied funds), and education is financed primarily out of these tax reimbursements. This means that the financing inequities that exist in the United States (both among states and among school districts within each state) do not exist in Australia.

In addition to what might be called general revenue sharing, additional Commonwealth funds specifically for education are distributed through specific purpose grants. Because inequities are relatively insignificant, this special federal funding for education actually operates to supplement or "top up" the basic educational program. By contrast, in the United States, federal funds for education often do not achieve this "topping up" effect because of fiscal disparities between school districts and among states. ${ }^{62}$

\section{B. Constitutional Power for Intervention in Education, the Role of the Courts and of the Executive}

1. Constitutional Authority. Most of the Commonwealth's express legislative powers are enumerated in section 51 of the constitution. ${ }^{63}$ Section 51 includes forty express legislative powers with the following preamble to the list of powers: "The Parliament shall, subject to this Constitution, have power to make laws for the peace, order, and good government of the Commonwealth with respect to . . . "These enumerated legislative powers are concurrent, that is, the fact that these specific grants of power have been made to the Commonwealth does not subtract anything from the states' general powers to make laws for the peace, order, and good government of the states. ${ }^{64}$

raise revenues independently is confined to such minor taxes as the payroll tax, automobile tax, stamp duties, probate and inheritance taxes, land tax, gambling tax, and liquor tax. $I d$. at 108

58. See id. at l15-16.

59. Id. at 117 .

60. AUSTL. Const. $\S 96$ (although section 81 is sometimes also relied upon).

61. "In 1959 the Commonwealth introduced a system of financial assistance grants in place of the tax reimbursement arrangements. Under [this] system, grants increased not merely by reference to changes in population and wages, but also in accordance with something called a 'betterment' factor." J. McMillan, G. Evans \& H. STOREY, supra note 6, at 122. Under the current scheme, introduced in 1982-83, the states share in a grant based on a fixed percentage, about 20 percent, of total (not just income tax) Commonwealth taxation collections. Id. at 123.

62. For a discussion of the patterns of allocation of federal aid to education in the United States, see generally J. Berke \& M. Kirst, Federal Aid to Education: Who Benefits? Who Governs? (1972); Berke \& Kirst, The Federal Role in American School Finance: A Fiscal and Administrative Analysis, 61 GEO. L.J. 927 (1973).

63. Compare U.S. Const. art. I, §8.

64. Some of the legislative powers in section 51 are, of course, exclusive to the Commonwealth because their subject matter is inherently beyond the competence of the states or because other parts 
As noted above, the only provision expressly referring to education is the amendment adopted by referendum ${ }^{65}$ in 1946 , permitting the Commonwealth Parliament to "make laws . . . with respect to . . . benefits to students."66 This provision, however, does not appear to lend itself to a broad interpretation of the extent of Commonwealth power over education, or at least it has not been so interpreted. Thus, with the almost total absence of express constitutional authority for federal intervention in education, coupled with the absence of an Australian equivalent to the equal protection clause ${ }^{67}$ from which such authority might be implied, there appears to be no constitutional basis for the Commonwealth's imposing on the states unfunded mandates analogous to such U.S. statutes as Title VI of the Civil Rights Act of 1964, Title IX of the Education Amendments of 1972, or section 504 of the Rehabilitation Act of 1973, and their implementing regulations. ${ }^{68}$

One possible source of constitutional authority, however, may lie in the external affairs power, ${ }^{69}$ discussed in part III of this article. Another is section 96 of the Australian Constitution, similar to the taxing and spending clause of the U.S. Constitution ${ }^{70}$ which provides authority in this country for federal grants-in-aid to education. The U.S. statutes frequently include extensive conditions that operate similarly to some of the civil rights mandates. ${ }^{71}$ The U.S. Supreme Court has repeatedly taken a broad view with respect to the

of the constitution exclude the states from acting in the area. See J. McMrllan, G. Evans \& H. STOREY, supra note 6, at 42-43. See generally id. at 39-67.

Section 51 concludes with a provision that is similar to the "necessary and proper" clause in the U.S. Constitution, U.S. Const. art. I, $\S 8, \mathrm{cl}$. 18. The Australian provision states that Parliament shall have power to make laws with respect to "matters incidental to the execution of any power vested by this Constitution in the Parliament or in either House thereof, or in the Government of the Commonwealth, or in the Federal Judicature, or in any department or officer of the Commonwealth." Austl. Const. $\S 51$ (xxxix).

65. The principal mechanism for amending the Australian Constitution is by referendum under section 128 of the constitution. That section provides that the proposed law for amending the constitution be passed by a majority of each house of the Parliament. Not less than two or more than six months after its passage through both houses, the proposed law is to be submitted in each state to the electors qualified to vote in that state for the election of members of the House of Representatives. A proposed law must be approved both by a majority of all the electorate voting and also by a majority of the electors voting in a majority of the states. AustL. Const. $\$ 128$. Those requirements have proved very hard to satisfy. Since federation, only eight of thirty-six such proposed amendments have been approved. J. McMillan, G. Evans \& H. Storey, supra note 6, at 359.

66. Austl. Const. $\$ 51$ (xxiiiA). The full provision covers a range of social services. Parliament may legislate with respect to "the provision of maternity allowances, widows' pensions, child endowment, unemployment, pharmaceutical, sickness and hospital benefits, medical and dental services (but not so as to authorize any form of civil conscription), benefits to students and family allowances." Austl. Const. $\$ 51$ (xxiiiA). See discussion supra note 53.

67. See discussion supra note $\mathbf{3 2 .}$

68. Civil Rights Act of 1964, tit. VI, 42 U.S.C. $\$ \S 2000$ d to 2000 d-4 (1982); 34 C.F.R. $\$ \S 75,76$, 100, 222, 700 (1984); Education Amendments of 1972, tit. IX, 20 U.S.C. $\$ \S 1681-1686$ (1982); 34 C.F.R. $\S \S 106,122$ (1984); Rehabilitation Act of 1973, $\$ 504,29$ U.S.C $\$ 794$ (1982); 34 C.F.R. $\S \S 104,222,300$ (1984). Since these statutes withhold other federal funds when their provisions are violated, the authority for these statutes may also lie in the taxing and spending power of article I, section 8, clause 1 of the U.S. Constitution, as well as in section 5 of the fourteenth amendment.

69. Austl. Const. $\$ 51$ (xxix).

70. U.S. Const. art. I, $\S 8, \mathrm{cl}$. 1 .

71. See, e.g., Education for All Handicapped Children Act of 1975, 20 U.S.C. $\S \S 1232$, 140I, 14051406 , 14ll-1420, 1453 (1982). 
scope of Congress' power to condition the receipt of federal grants enacted pursuant to the spending clause. ${ }^{72}$ Although the Australian provision explicitly says any federal grant can be conditioned ${ }^{73}$ whereas the U.S. approach has been developed through court interpretation, there has been in Australia little reliance on section 96 as a basis for extensive conditioning of specific purpose grants, ${ }^{74}$ and Australia imposes relatively few conditions on those grants, at least compared with the United States. Whether section 96 could be used as authority for conditions such as those included in the Education for All Handicapped Children Act or Title I of the Elementary and Secondary Education Act will be discussed in part IV of this article.

2. The Role of the Courts. The policymaking role of courts in Australia is very different from that of courts in the United States. At about the same time that the legislative and executive branches of the federal government were expanding their involvement in education, the U.S. federal courts began to assume a significant policymaking role in the field of education beginning with Brown ข. Board of Education.75 Following Brown, for the remainder of the 1950 's, the courts were primarily concerned with implementing the constitutional requirement that no student be denied an equal educational opportu-

72. In King v. Smith, 392 U.S. 309 (1968), where the Court upheld a condition of the Aid to Families with Dependent Children program against state regulations which would have diminished its effectiveness, the Court stated: "There is of course no question that the Federal Government, unless barred by some controlling constitutional provision, may impose the terms and conditions upon which its money allotments to the States shall be disbursed . . . . Id. at $333 \mathrm{n} .34$. Similar statements have been made with respect to conditions imposed on federally funded construction projects, see Fullilove v. Klutznick, 448 U.S. 448, 474 (1980) (10 percent of funds for public works project required to be used to procure services or supplies from "minority business enterprises"); requirements under Title VI of the Civil Rights Act of 1964 banning discrimination in "any program or activity receiving Federal financial assistance," see Lau v. Nichols, 414 U.S. 563, 569 (1974) (failure of school district to provide affirmative language assistance to students of Chinese ancestry who spoke little or no English); and legislation providing that no state official employed "in connection with any activities . . . financed in whole or in part by [federal funds] shall . . . take any active part in political management or in political campaigns," see Oklahoma v. United States Civil Serv. Comm'n, 330 U.S. 127, 143-44 (1947) (under Section 12(a) of the Hatch Act, 54 Stat. 767 (1940) (current version at 5 U.S.C. $\$ \S 1501(4), 1502$ (1982)), agency may withhold funds in an amount equaling two years' salary); see also, e.g., Pennhurst State School v. Halderman, 451 U.S. 1, $17-18$ (1981) (reaffirming power to condition funds but finding no effective condition imposed). Although the Court has announced that the power is not without limits, its attempts to articulate the content of those limits are remarkably vague. See Pennhurst, 451 U.S. at $17 \mathrm{n} .13$ (and cases cited therein). "Requiring States to honor the obligations voluntarily assumed as a condition of federal funding . . . simply does not intrude on their sovereignty. . . . If the conditions were valid, the State had no sovereign right to retain funds without complying with those conditions." Bell v. New Jersey, 103 S. Ct. 2187, 2197 (1983). National League of Cities v. Usery, 426 U.S. 833 (1976), left open the question whether grant conditions that intrude upon state sovereignty with respect to "integral operations of state governments" would be upheld. Id. at 852 n.17. The D.C. Circuit has recently noted that the most diligent inquiry will not "uncover any instance in which a court has invalidated a funding condition." Oklahoma v. Schweiker, 655 F.2d 401, 406 (1981); see also cases cited id. at 406 n.9.

For a general description of specific grant conditions enacted pursuant to the spending clause, see P. HAY \& R. RotUnDa, supra note 6 , at 173-81.

73. "During a period of ten years after the establishment of the Commonwealth and thereafter until the Parliament otherwise provides, the Parliament may grant financial assistance to any State on such terms and conditions as the Parliament thinks fit." Austr. Const. $\$ 96$.

74. See discussion infra at text accompanying notes 287-305.

75. 347 U.S. 483 (1954). 
nity because of his or her race. While their involvement in the dismantling of dual school systems has continued unabated, ${ }^{76}$ the U.S. courts have also become involved in other areas which long had been the prerogative of school authorities. ${ }^{77}$ In the last 15 years, the U.S. Supreme Court has reviewed cases involving nearly every major area of educational policy: school curriculum questions, ${ }^{78}$ student rights of free expression and of nondisruptive protest, ${ }^{79}$ exemptions from state compulsory school attendance laws, ${ }^{80}$ school finance reform ${ }^{81}$ gender discrimination, ${ }^{82}$ discrimination against handicapped students, ${ }^{83}$ bilingual or English-language instruction for those with limited English skills, ${ }^{84}$ school personnel policies, ${ }^{85}$ student discipline, ${ }^{86}$ and liability of school officials for violating the civil rights of students. ${ }^{87}$ The involvement of the lower federal courts and of state courts in educational issues has been even more pervasive, including such areas as the tracking and classification of students ${ }^{88}$ and minimal competency testing. ${ }^{89}$

There is no such tradition of court intervention in educational policy issues in Australia. The federal courts are only 6 years old and do not have a general "arising under" jurisdiction. ${ }^{90}$ Since the federal courts have a narrow jurisdiction, most cases that might involve education would come up through the state courts and then be appealed to the High Court. Most cases, how-

76. See e.g., Washington v. Seattle School Dist. No. 1, 455 U.S. 934 (1982); Crawford v. Board of Educ., 455 U.S. 904 (1982); Columbus Bd. of Educ. v. Penick, 443 U.S. 449 (1979).

77. See generally M. Yudof, D. Kirp, T. van Geel \& B. Levin, Educational Policy and the LaW (2d ed. 1984); Levin, The Courts, Congress, and Educational Adequacy: The Equal Protection Predicament, 39 MD. L. REv. 187 (1979).

78. See, e.g., Board of Educ. v. Pico, 457 U.S. 853 (1982); Milliken v. Bradley, 433 U.S. 267 (1977); Epperson v. Arkansas, 393 U.S. 97 (1968).

79. Tinker v. Des Moines Indep. Community School Dist., 393 U.S. 503 (1969),

80. Wisconsin v. Yoder, 406 U.S. 205 (1972).

81. San Antonio Indep. School Dist. v. Rodriguez, 411 U.S. 1 (1973).

82. Mississippi Univ. for Women v. Hogan, 458 U.S. 718 (1982).

83. See, e.g., Irving Indep. School Dist. v. Tatro, 104 S. Ct. 3371 (1984); Board of Educ. v. Rowley, 458 U.S. 176 (1982); Southeastern Community College v. Davis, 442 U.S. 397 (1979).

84. Lau v. Nichols, 414 U.S. 563 (1974).

85. See, e.g., Perry Educ. Ass'n v. Perry Local Educators' Ass'n, 460 U.S. 37 (1983); Hortonville Joint School Dist. No. 1 v. Hortonville Educ. Ass'n, 426 U.S. 482 (1976); Cleveland Bd. of Educ. v. La Fleur, 414 U.S. 632 (1974).

86. Goss v. Lopez, 419 U.S. 565 (1975); Ingraham v. Wright, 430 U.S. 651 (1977).

87. Wood v. Strickland, 420 U.S. 308 (1975).

88. See, e.g., Larry P. v. Riles, 502 F.2d 963 (9th Cir. 1974).

89. See, e.g., Debra P. v. Turlington, 730 F.2d 1405 (llth Cir. 1984).

The constitutional rights of teachers also expanded during the period of the sixties and early seventies-encompassing such diverse areas as free speech, see, e.g., Givhan v. Western Line Consol. School Dist., 439 U.S. 410 (1979); Mount Healthy City School Dist. Bd. of Educ. v. Doyle, 429 U.S. 274 (1977); Pickering v. Bd. of Educ., 391 U.S. 563 (1968), and the ways in which teachers are certified, see, e.g., United States v. North Carolina, 400 F. Supp. 343 (E.D.N.C. 1975), vacated, 425 F. Supp. 789 (E.D.N.C. 1977), as well as issues involving the right to bargain collectively, see, e.g., McLaughlin v. Tilendis, 398 F.2d 287 (7th Cir. 1968); National Educ. Ass'n v. Board of Educ., 212 Kan. 74 1, 512 P.2d 426 (1973); cf. Abood v. Detroit Bd. of Educ., 431 U.S. 209 (1977), and to strike or apply other sanctions, see, e.g., School Dist. v. Holland Educ. Ass'n, 380 Mich. 314, 157 N.W. 2d 206 (1968), and the right to bargain about various aspects of educational policy, see, e.g., City of Beloit v. Wisconsin Employment Relations Comm'n, 73 Wis. 2d 43, 242 N.W. 2d 231 (1976); San Mateo City School Dist. v. Public Employment Relations Bd., 33 Cal. 3d 850, 663, P.2d 523, 191 Cal. Rptr. 800 (1983). See generally, Edwards, The Emerging Duty to Bargain in the Public Sector, 71 Mich. L. Rev. 885 (1973). 90. See supra note 39 . 
ever, are not heard by the High Court as a matter of right. ${ }^{91}$ Moreover, even if Australia had a tradition of court intervention in education, the results would be very different there than in the United States, since the constitutional issues involving education that arise under the first, fourth, and fourteenth amendments in the United States would not arise in Australia.

3. The Role of the Executive. The federal structure for governing education in Australia is headed by a Minister of Education, who is appointed by the party in power and has a seat in Parliament. The Minister will change as the party in control changes. There is also a Secretary of Education, a top civil servant, who is the permanent head of the Department of Education. ${ }^{92}$ The Secretary of Education is responsible for administering funds for student aid, policymaking, and providing advice to the Minister. ${ }^{93}$

Labor government reforms in 1972 created a Schools Commission whose four full-time and six part-time members dispensed almost all specific purpose Commonwealth funds for elementary and secondary education, including funds for nongovernment schools (with the principal exception of funds for student aid). ${ }^{94}$ Although the Commission has separate statutory authority, it submits its budget to the Department of Education and to the Secretary of Education. ${ }^{95}$

\section{The Schools Commission's Statutory Authority}

The States Grants (Schools) Act 1973 originated financial assistance to

91. See supra note 40

92. When there has been a party change as a result of an election, if the incoming government wishes to remove the Secretary of Education, it can only be done by transferring him to another secretarial position in another department or by making him an ambassador to a foreign country, since Department Secretaries carry ambassadorial rank. Interview with Peter Tannock (July 9, 1983); Interview with Dr. Peter Wilenski (July 8, 1983) (memorandum on file with author).

93. Interview with Dr. Peter Wilenski, supra note 92. The major function of the Commonwealth Education Department appears to be to process and handle applications for student assistance. The Department provides assistance to students in secondary education who are 16-years-old and older (about $\$ 16$ per week, given to the student's parent). This stipend is to encourage students to stay in school for the last few years and to encourage the parents not to rely on their children's earnings. There is also a program of assistance to students enrolled in tertiary (higher) education. Since tertiary education is free, these grants are for living expenses; tertiary students receive the funds directly. The major financial aid programs for youth are all strictly income-tested (need-based). Id.

The Department administers the Youth-to-Work Transition grants program, but the remaining specific purpose grants programs are administered by the Commonwealth Schools Commission. See infra text accompanying notes 94-95.

Although responsibility for running the schools in the Northern Territory was recently transferred from the Commonwealth to the Northern Territory, the Australian Capital Territory (ACT) schools and those in other nonstate areas are run by the Commonwealth government, as are the schools on the government aboriginal reserves.

94. In 1972, the Labor Party appointed the Interim Committee for the Australian Schools Commission. This Committee resulted in a report in 1973 (The Karmel Report-so named for Peter Karmel, the Chair of the Committee) that led to the passage of the States Grants (Schools) Act 1973, 1973 Austl. Acts 1407, and the Schools Commission Act 1973, 1973 Austl. Acts 1398.

95. There is also a Tertiary Education Commission that gives out all Commonwealth higher education money. Currently, all institutions of higher education are wholly supported by federal funds. 
Australia's schools through specific purpose grants. ${ }^{96}$ Special federal program funds for education were divided into seven categories, the first two being essentially block grants:

(l) general building grants (capital costs);

(2) general recurrent expenditures (operating expenses);

(3) grants for school library projects;

(4) grants for both capital and operating expenses for disadvantaged schools;

(5) grants for special schools for the handicapped;

(6) grants for teacher development; and

(7) grants for special experimental projects designed to promote innovation or change. 97

These specific purpose funds are paid to the states with minimal conditions. The funds must be used by the state for the specified purposes, such as building projects or recurring expenses in connection with government or nongovernment primary and secondary schools in the state. ${ }^{98}$ The state must also furnish the Minister evidence, within six months after the end of the year in which the payment is made, that the funds were spent for the designated purpose. If the state fails to meet these two conditions, the state must repay an amount equal to the payment it received. In addition, the state must report statistical and other information with respect to its schools. Even for the more narrowly focused grants, such as libraries or disadvantaged schools, there appear to be no conditions other than that the funds be spent for the particular purpose (e.g., librarian training courses), and that there be some fiscal accounting to the Commonwealth at the end of the grant period.

A federal policy which has only seven specific target areas (two of which are essentially block grants for capital and operating expenses) is very different from the often complex federal education legislation in the United States. ${ }^{99}$ Moreover, the bulk of Australian expenditures for education are financed by the states from the general revenue sharing funds returned to the states by the Commonwealth under the 1942 Uniform Tax Scheme. ${ }^{100}$ The remainder comes from financial assistance provided by the Schools Commission under the States Grants (Schools) Act. ${ }^{101}$ The Schools Commission paid

96. States Grants (Schools) Act 1973, 1973 Austl. Acts 1407.

97. Id. $\S \S 17-25,1973$ Austl. Acts at 1426-33.

98. See id. $\S 4(1), 1973$ Austl. Acts at 1415. As noted earlier, recipients of specific purpose funds include both public schools (called government schools in Australia) and nonpublic or parochial schools (called nongovernment schools). Another condition is that the Commonwealth may not fund a building project whose sole or principal object is either to increase the maximum number of students that may be provided for at government primary or secondary schools in the state, or to provide housing for teaching or other staff in any capital city. Id. $\$ 5$ (1)(a)(i)-(ii), 1973 Austl. Acts at 1415 .

99. Compare the statutory conditions attached to grants for disadvantaged schools in the States Grants (Schools) Act 1973, \$27, 1973 Austl. Acts 1407, 1414, with the conditions in Title I of the Elementary and Secondary Education Act of 1965, 20 U.S.C. $\S \S 2701-2854$ (1982). In Australia, grants to the states for operating and capital expenses supplement the funds provided through consolidated revenues (these latter funds are not restricted to specific uses: states can decide what proportion to spend on highways, on education, and so forth).

100. See supra notes 54-61 and accompanying text.

101. A percentage of both the state funds (whose sources are partly Commonwealth revenue, partly state revenue) and the Commonwealth specific purpose funds for education go to nongovern- 
about 50 percent of the states' total capital budget in 1983 (the usual figure is closer to 30 percent) and 10 percent of the states' operating budget. This 10 percent is broken down into 7 percent for the "block grants" for general operating costs in the States Grants (School Assistance) Act, known as "recurrent expenditure," and 3 percent for the five special purpose grants enumerated above. ${ }^{102}$ And, as already noted, there are only a limited number of objectives or conditions for these grants, primarily having to do with fiscal reporting.

Since the 1973 Act, Australia has only added two categories of functions receiving specific purpose grants. One is migrant education, comprised of English-as-a-Second-Language (ESL) programs and part-time ethnic education programs designed to teach a language other than English "that is the first language of peoples who have migrated to Australia." 103 The other is multicultural education, which provides programs "designed to take account of the culture of Aboriginal or immigrant peoples."'104 The current Commonwealth grants programs will be discussed in part IV of this article.

\section{III}

\section{The External Affairs Power}

As the previous section indicated, Australia has not used its section 96 power significantly to condition specific purpose grants to protect special pupil populations, at least when compared with some of the U.S. statutes. ${ }^{105}$ More important, the Australian Constitution has no guarantees of individual rights and liberties, such as those that appear in the U.S. Constitution's Bill of Rights and the fourteenth amendment, ${ }^{106}$ that would provide the authority for

ment schools, including sectarian schools. See States Grants (Schools) Act 1973, scheds. 1-6, 1973 Austl. Acts 1407, 1456-59.

102. Interview with members of Commonwealth Schools Commission (July 8, 1983) (memorandum on file with author). For tables showing the disbursement of funds to the states, see States Grants (Schools Assistance) Amendment Act 1982, 1982 Austl. Acts 276; States Grants (Schools) Act 1973, 1973 Austl. Acts 1407, 1456-59. Total funding for specific purpose education grants disbursed by the Schools Commission doubled in the ten-year period since the passage of the initial act. Compare States Grants (Schools) Act 1973, 1973 Austl. Acts 1407, 1456-59 with States Grants (Schools Assistance) Amendment Act 1982, 1982 Austl. Acts 276.

103. States Grants (Schools Assistance) Act 1982, § 3(1), 1982 Austl. Acts 1745, 1754.

104. Id., 1982 Austl. Acts at 1752.

105. Compare States Grants (Schools) Act 1973, §§ 35-42, 1973 Austl. Acts 1407, 1438-44 (Grants in Respect of Special Schools for Handicapped Children) with Education for All Handicapped Children Act, 20 U.S.C. $\$ \S 1400-1461$ (1982); compare States Grants (Schools) Act 1973, \$§ 2634, 1973 Austl. Acts 1407, 1433-38 (Grants for Disadvantaged Schools) with Title I of the Elementary and Secondary Education Act of 1965, 20 U.S.C. \$§ 2701-2854 (1982).

106. See supra note 32 and accompanying text. For various reasons, discussed supra note 32 , the founding fathers rejected the need to include in the Australian Constitution anything like the Bill of Rights. Only a few guarantees, which have been narrowly interpreted, appear in the Australian Constitution. For example, Austl. Const. $\$ 51$ (xxxi) requires that the taking of property by the Commonwealth be on "just terms." Compare U.S. Const. amend. V ("Private property [shall not] be taken for public use, without just compensation"). Section 80 guarantees a trial by jury for any person charged with an indictable Commonwealth offense. (This requirement has frequently been avoided by providing that an offense can be tried summarily rather than by indictment.) Section 116 provides that the Commonwealth "shall not make any law for establishing any religion, or for imposing any religious observance, or for prohibiting the free exercise of any religion . . . This has been inter- 
civil rights statutes.

The only attempt in Australia to establish broad-based human rights guarantees was made in 1973 by the Labor government. A human rights bill was introduced in the Senate that would have invalidated Commonwealth and state laws and practices that infringed a wide variety of fundamental rights and freedoms. ${ }^{107}$ The authority for the human rights bill was said to be the external affairs power, section 51 (xxix). The bill, however, was not voted on in Parliament. ${ }^{108}$

Several recent cases, however, have indicated that the external affairs power, section 51 (xxix), may be the source of constitutional authority for a greater Commonwealth role in education, particularly in the civil rights area. The two major cases dealing with the external affairs power are Koowarta $v$. Bjelke-Petersen ${ }^{109}$ and Commonwealth v. Tasmania (the Tasmanian Dam Case). ${ }^{110}$ These cases drew upon the precedents developed in several earlier cases.

\section{A. Early Cases}

The principal precedent case is The King $v$. Burgess, ${ }^{11}$ which reviewed the conviction of a pilot who flew intrastate ${ }^{12}$ without a federal license in violation of regulations requiring such a license. The regulations were promulgated pursuant to an act implementing an international air navigation convention. The High Court held that the Commonwealth could regulate flights occurring wholly within a state since, as a signatory to the Paris Air

preted, however, to permit Commonwealth financial assistance to go to sectarian schools. See Victoria ex rel. Black v. Commonwealth, 146 C.L.R. 559 (Austl. 1980). See generally I. Birch, State-Aid at the Bar: of DOGS and a Bone (Nov. 18, 1982) (unpublished manuscript) ("DOGS" refers to Defense of Government Schools, the plaintiff organization in Victoria ex rel Black.). Moreover, since there is no fourteenth amendment, the states are not similarly barred from interfering with the free exercise of any religion or from establishing any religion. See Birch, Non-Public Education in the U.S. and Australia, in Contemporary Issues in Educational Policy 203 (1983). Finally, section 117, paralleling the privileges and immunities clauses both of article IV, section 2 and of section I of the fourteenth amendment of the U.S. Constitution, provides that "a subject of the Queen, resident in any State, shall not be subject in any other State to any disability or discrimination which would not be equally applicable to him if he were a subject of the Queen resident in such other State."

This does not mean that Australia does not protect individual rights. There is heavy reliance on various accepted practices and on the doctrine of natural justice which, for example, operates to entitle an individual to notice and a hearing before being deprived of any right, liberty, or property.

J. McMillan, G. Evans \& H. Storey, supra note 6, at 320-2l.

107. J. McMillan, G. Evans \& H. Storey, supra note 6, at 320.

108. In 1981, a Human Rights Commission was established by statute, Human Rights Commission Act 1981, 1981 Austl. Acts 254, based on the United Nations International Covenant on Civil and Political Rights, opened for signature Dec. 19, 1966, Annex to G.A. Res. 2200, 21 U.N. GAOR Supp. (No. 16) at 52, U.N. Doc. A/6316 (1966). The Commission conducts research and educational activities, advises whether Commonwealth legislation is compatible with the U.N. Covenant, and investigates complaints of human rights violations. The Human Rights Commissioner, however, has no enforcement powers. See also Racial Discrimination Act 1975, 1975 Austl. Acts 347, discussed infra text accompanying notes $129-34$.

109. 39 Austl. L.R. 417 (1982).

110. 46 Austl. L.R. 625 (1983).

111. 55 C.L.R. 608 (Austl. 1936).

112. Goya Henry was an eccentric stunt fyer who flew paying passengers in an ancient aircraft over city areas. One story has it that he flew his plane under Sydney Harbour Bridge. See J. McMillan, G. Evans \& H. Storey, supra note 6, at 59. 
Convention, the Commonwealth was obligated to control all domestic airspace.

This case required the Court to examine the scope of section 51 (xxix). A majority of the justices viewed that section as providing broad, independent legislative power potentially reaching any subject matter that could be the object of international agreement and limited only by express constitutional prohibitions. Two justices would have extended the power beyond the implementation of an international agreement to reach "matters of concern to Australia as a member of the family of nations."113 At the other end of the spectrum, one justice would have limited the scope of the section 51(xxix) power to legislation implementing only those international agreements which bound the Commonwealth in reference to some matter "indisputably international in character". 114 Another justice strongly implied that he would require a treaty to be of "sufficient significance" to be a "legitimate" subject of international concern, arguing that the section 51 (xxix) power was limited by implied as well as express constitutional prohibitions. ${ }^{115}$

While the High Court in Burgess apparently endorsed the Commonwealth's authorization to enact legislation pursuant to section 51 (xxix), it reversed the defendant's conviction: four of the five justices required that there be fairly strict congruence between the statute (and regulations) and the objectives of the international agreement. The regulations in question were held invalid as too incidental to the reach of the agreement. The dissenting justice on this point, however, argued that once an act of Parliament was found to be within the section 51 (xxix) power, its implementation should be liberally construed to include incidental subjects. ${ }^{16}$

The Burgess case laid the groundwork for the use of the external affairs power domestically. After Burgess, the major questions addressed in subsequent litigation have been (l) whether the subject matter of an international agreement is an external affair and (2) to what extent the agreement can be implemented domestically (how strict a congruence is required between the international agreement and the domestic legislation)..$^{117}$

Airlines of N.S.W. Proprietary, Ltd. v. New South Wales 118 upheld regulations governing intrastate aviation that were enacted to implement the Chicago Convention on International Civil Aviation of 1944. The Court found these regulations "appropriate and adapted"119 to the ends of the treaty, even though the treaty itself did not specifically mention intrastate aviation. The decision contains statements by a number of justices expressly recognizing Commonwealth power under section 51 (xxix) to legislate in areas normally

113. 55 C.L.R. 687 (Austl. 1936) (Evatt \& McTiernan, JJ.).

114. Id. at 669 (Dixon, J.).

115. Id. at 658 (Stark, J.).

116. Id. at 659-60 (Stark, J.).

117. Van Son, The Australian Constitution: The External Affairs Power and Federalism, 12 CaL. W. INT'L L.J. 46, 54-55 (1982).

118. 113 C.L.R. 54 (1965).

119. Id. at 86 (Barwick, C.J.). 
reserved to the states. ${ }^{120}$

In The King $v$. Sharkey, ${ }^{121}$ involving the conviction of a Communist leader in Australia for seditious acts directed not at Australia but at a member of the Dominion, Chief Justice Latham apparently went further. He indicated that the existence of a treaty or convention was not a prerequisite to the exercise of the section 51 (xxix) power. ${ }^{122}$ Australia's desire to maintain "friendly relations with other dominions," he found, was a sufficient basis for legislation authorized under that section. ${ }^{123}$ It should be noted, however, that the case involved a Crown Statute, later adopted by Australia, rather than original Commonwealth legislation. ${ }^{124}$

\section{B. The Koowarta Case}

Koowarta $v$. Bjelke-Petersen, ${ }^{125}$ which upheld the Racial Discrimination Act 1975, arose when Koowarta, an Aborigine from Queensland, sought on behalf of himself and members of his tribe to obtain a Crown leasehold on land in Queensland. Negotiations led to a contract for the purchase of the lease. Under both the contract and a Queensland law, sale or transfer of this lease was subject to approval by the Queensland Minister of Lands. The Minister denied approval because the request came within the declared policy of the Queensland Cabinet: "The Queensland Government does not view favourably proposals to acquire large areas of additional freehold or leasehold land for development by Aborigines or aboriginal groups in isolation." 126

Koowarta claimed that the Queensland Minister of Lands had acted unlawfully under the Racial Discrimination Act 1975, passed by the Commonwealth to implement the International Convention on the Elimination of All Forms of Racial Discrimination, ${ }^{127}$ to which Australia was a signatory. Article $2(l)$ of the Convention requires States Parties to "pursue by all appropriate means" a policy of eliminating racial discrimination by any persons, groups, or organizations, "including legislation as required by circumstances."128 Article V. of the Convention provides that

States Parties undertake to prohibit and to eliminate racial discrimination in all its

120. See, e.g., id. at 82 (Barwick, C.J.), 115 (Kitto, J.), 125-26 (Taylor, J.). A related case was New South Wales v. Commonwealth (the Submerged Lands Case), 135 C.L.R. 337 (Austl. 1975). In this case, a Commonwealth act (enacted pursuant to an international convention) claimed Commonwealth jurisdiction of contiguous marine areas. The majority upheld the act against the states' claim that if the subject matter is geographically external to Australia, there need not be any reciprocity of international interests.

121. 79 C.L.R. 121 (Austl. 1949).

122. Id. at 135-38.

123. Id. at 137. A second justice agreed with this point. Id. at 163 .

124. In an earlier case, Ffrost v. Stevenson, 58 C.L.R. 528 (Austl. 1937), two of five justices would have upheld legislation providing for extradition of fugitives from New Guinea under section 51 (xxix). That legislation was based on a Crown act later adopted by Australia.

125. 39 Austl. L.R. 417 (1982).

126. Decision of September 1972, quoted in Koowarta, 39 Austl. L.R. at 420 (Gibbs, C.J.).

127. Opened for signature March 7, 1966, 660 U.N.T.S. 195, G.A. Res. 2106, 20 U.N. GAOR Supp. (No. 14) at 47, U.N. Doc. A/6104 (1965) (hereinafter cited as International Convention on the Elimination of All Forms of Racial Discrimination).

128. Id. art. 2(1). 
forms and to guarantee the right of everyone, without distinction as to race, colour, or national or ethnic origin, to equality before the law, notably in the enjoyment of the following rights: . . . the right to own property alone as well as in association with others ... . 129

\section{Section 9 of the Racial Discrimination Act 1975 declares that it is}

unlawful for a person to do any act involving a distinction, exclusion, restriction or preference based on race, colour, descent or national or ethnic origin which has the purpose or effect of nullifying or impairing the recognition, enjoyment or exercise, on an equal footing, of any human right or fundamental freedom . . . 130 .

The Act adds that the reference to "a human right or fundamental freedom" includes a reference to any right found in article $\mathrm{V}$ of the Convention. ${ }^{131} \mathrm{Sec}-$ tion 12(1) of the Act specifically forbids discrimination in the sale or disposition of property. ${ }^{132}$ The Act also created a right of action for a "person aggrieved" 133 and provided remedies, including injunction and damages. ${ }^{134}$

Koowarta brought suit under the Racial Discrimination Act. The defendants argued that the Act was unconstitutional, with the Court limiting argument to the validity of sections 9 and 12 of the Act under section 51(xxix) of the constitution. ${ }^{135}$

The Koowarta case is significant because the Commonwealth legislation dealt with purely domestic acts in the context of moral commitments found appropriate by international agreement. Previous cases had dealt with less abstract subject matter, such as internationally shared air or sea space or crimes committed against or in other states. ${ }^{136}$ The issue was thus more clearly drawn in Koowarta: whether the Commonwealth, under section 51 (xxix), could enact laws to implement any treaty on any subject matter, despite express constitutional limitations on Commonwealth powers in relation to state powers.

The issue whether sections 9 and 12 of the Racial Discrimination Act were

129. Id. art. 5.

130. Racial Discrimination Act 1975, $\$ 9(1), 1975$ Austl. Acts 347, 352.

131. Id. $\S 9(2), 1975$ Austl. Acts at 352 .

132. Section 12(1) of the Act, 1975 Austl. Acts at 353, provides:

It is unlawful for a person, whether as a principal or agent-

(a) to refuse or fail to dispose of any estate or interest in land, or any residential or business accommodation, to a second person;

(b) to dispose of such an estate or interest or such accommodation to a second person on less favorable terms and conditions than those which are or would otherwise be offered;

(c) to treat a second person who is seeking to acquire or has acquired such an estate or interest or such accommodation less favorably than other persons in the same circumstances;

(d) to refuse to permit a second person to occupy any land or any residential or business accommodation; or

(e) to terminate any estate or interest in land of a second person or the right of a second person to occupy any land or any residential or business accommodation,

by reason of the race, colour or national or ethnic origin of that second person or of any relative or associate of that second person.

133. Id. $\S 24(1), 1975$ Austl. Acts at 357 .

134. Id. $\$ 25,1975$ Austl. Acts at 358 .

135. Section 51 (xxvi), which grants the Commonwealth legislative powers with respect to "the people of any race for whom it is deemed necessary to make special laws," was also involved.

136. See supra text accompanying notes 111-18. 
valid under the external affairs power had to be analyzed in two steps. First, was the subject matter within the concept "external affairs"? Second, if so, was the scope of the challenged legislation reasonably appropriately designed to effectuate the obligation incurred? The State of Queensland conceded that sections 9 and 12 conformed to the terms of the Convention. Thus the only question was whether the subject matter fell within the concept of external affairs. By a narrow three-to-four majority, the High Court held that the Racial Discrimination Act 1975 was properly a law with respect to external affairs.

The High Court majority consisted of Justices Mason, Murphy, Brennan and Stephen. The first three took a broad view of what constituted an "external affair." A subject matter, in their view, becomes an "external affair" upon becoming the object of a treaty. Justice Mason held that any treaty obligation, if not entered into solely in order to be able to utilize the authority in section 51(xxix), is an external affair, although exercise of that authority is limited by any express or implied constitutional restrictions. ${ }^{137}$ The fact that a power is normally reserved to the state, however, is not such a restriction. According to Justice Mason, "[i]t is very difficult to see why [an implementing] law would not be a law with respect to an external affair, once it is accepted that the treaty is an external affair." 138 The concept of "external affairs" is fixed and unchanging. However, recent expansion in international cooperation raises the potential for Commonwealth activity in new legislative areas, since "it is a Constitution we are interpreting." 139

Justice Mason seemed to go further, however, in maintaining that the existence of "international concern" over a topic would create an "external affair" within the meaning of section 51 (xxix) even if Australia were not a party to a treaty with respect to the topic. For him, as for Justice Murphy, the existence of a treaty is not a necessary prerequisite to the exercise of the section 51 (xxix) power. "[A] matter which is of external concern to Australia having become the topic of international debate, discussion and negotiation constitutes an external affair before Australia enters into a treaty relating to it." 140 Any expansion of Commonwealth power into areas usually reserved to the states is justified to the extent necessary to allow Australia to participate in the international community. The rationale is that if Australia failed to meet its obligations, it would become the object of international discussion, disapproval, and perhaps even enforcement action by international bodies. ${ }^{141}$

Having once determined that the subject matter is within the purview of section 51 (xxix), Justice Mason takes the view that the power to enact imple-

137. Koowarla, 39 Austl. L.R. at 460.

138. Id. at 459 .

139. Id. at 462 (quoting Australian Nat'l Airways Proprietary, Ltd. v. Commonwealth, 71 C.L.R. 29, 81 (Austl. 1945) (Dixon, J.)). This is obviously reminiscent of Chief Justice Marshall's statement "it is a constitution we are expounding." McCulloch v. Maryland, 17 U.S. (4 Wheat.) 316, 407 (1819) (emphasis in original).

140. Koowarta, 39 Austl. L.R. at 466-67.

141. Id. at 468. 
menting legislation is broad and discretionary. As long as the legislation is appropriate and adapted to the enforcement of the Convention, rather than repugnant to it, the legislation should be upheld. ${ }^{142}$

Justice Murphy, who also took a very broad approach, shared Justice Mason's opinion that the existence of a treaty is not prerequisite to invoking section 51 (xxix) authorization. In his view, any act relating to matters of international concern such as "observance in Australia of international standards of human rights" 143 would provide the basis for laws reaching purely domestic matters even if there is no international agreement. With regard to racial discrimination, Justice Murphy noted that this century had seen the "greatest recognition of and also the greatest denial of human rights in all history."'144 Moreover, various U.N. agencies, declarations, and conventions had evidenced a great degree of international concern about the persistence of racial discrimination. ${ }^{145}$ Certainly, the concern of the Commonwealth with discrimination in Australia is related to its concern about discrimination elsewhere. "In the practical realm of international politics it would be futile for Australia to criticize racial discrimination or other human rights violations in other countries if it were to tolerate such discrimination within Australia."146 Like Justice Mason, Justice Murphy would not require precise congruence between the implementing act under section 51 (xxix) and the terms of the international agreement. ${ }^{147}$

Justice Brennan's opinion was somewhat more constrained, but he found that "[i]f Australia, in the conduct of its relations with other nations, accepts a treaty obligation with respect to an aspect of Australia's internal legal order, the subject of the obligation thereby becomes . . . an external affair and a law with respect to that subject [is within section 51 (xxix)]."148

The opinions of these three justices in Koowarta support a broad interpretation of the section 51 (xxix) power. However, Justice Stephen, whose vote was necessary for a majority in favor of an interpretation of section 51 ( $x x i x)$ that permits legislation to reach domestic matters, heavily qualified his agreement with the plurality, and agreed with the dissenters that mere entry into an international agreement does not generate an external affair. To come within section 51 (xxix), it is not enough that a law effectuate a treaty obligation. A "matter of international concern" must be involved, one which displays "the capacity to affect a country's relations with other nations . . . ."149 Thus, in his view, though "external affairs" is a fixed concept, its content "lies very much in the hands of the community of nations of which Australia forms a

\footnotetext{
142. See id. at 458,465 .

143. Id. at 473 .

144. Id. at 470 .

145. Id. at 471 .

146. Id.

147. See id. at 472.

148. Id. at 487.

149. Id. at 453 .
} 
part." 150 The prohibition of racial discrimination is clearly part of that content. Although it would appear that the Racial Discrimination Act is a Commonwealth intrusion into a legislative area previously exclusively left to the states, this was not, according to Justice Stephen, a redistribution in the federal balance, but only a growth in the content of "external affairs" reflecting "the new global concern for human rights and the international acknowledgment of the need for universally recognized norms of conduct. . . ."151 In his view, the subject matter must have to do with "such of the public business of the national government as relates to other nations or other things or circumstances outside Australia," 152 and any such legislation should receive intense scrutiny to assure "general international concern" or "especial concern to the relationship between Australia and [another] country." 153

Chief Justice Gibbs led the dissent, ${ }^{154}$ taking the view that Commonwealth laws implementing international agreements were invalid unless the provisions to which they gave effect specifically addressed external affairs. According to Justice Gibbs and the other dissenters, "external affairs" required that the subject matter of the provision involve a relationship with other countries or with persons or things outside Australia. The term "external affairs" as used in section 51 (xxix) thus was not coextensive with the treatymaking power. In this view, earlier cases, such as The King v.Burgess, ${ }^{155}$ Airlines of N.S.W. Proprietary, Ltd. v. New South Wales ${ }^{156}$ and New South Wales v. Commonwealth (the Submerged Lands Case)157 "had, in themselves, an international element; they affected the relations between Australia and other countries in some direct way." 158

The Koowarta case presented a different issue: whether Parliament can, under section 51 (xxix), effectuate "a treaty which deals with a matter that is entirely domestic and affects only Australians within Australia, and their relations to each other, and does not involve any trelationship [sic] between Australia or Australians and other countries or their citizens." 159 The only way in which international obligations could be given domestic effect, under the constitution, would be by state law unless the subject matter is within express grants of Commonwealth power elsewhere in the constitution. It could not, however, be done through the external affairs power alone. Thus, as Justice Wilson added in his dissenting opinion, the provisions of the Racial Discrimination Act 1975 lacked the necessary external aspect, since the conduct those

150. Id. at 454 .

151. Id.

152. Id. at 449 .

153. Id. at 453 .

154. Id. at 419-45. Justice Aicken concurred in the dissent with no separate opinion, see id. at 41719 , and Justice Wilson also joined in the dissent, to which he added "supplementary remarks." Id. at 475-82.

155. 55 C.L.R. 608 (Austl. 1936); see supra text accompanying notes 111-17.

156. 113 C.L.R. 54 (Austl. 1965); see supra text accompanying notes 118-20.

157. 135 C.L.R. 337 (Austl. 1975); see supra note 120.

158. Koowarta, 39 Austl. L.R. at 433.

159. Id. at 434 . 
sections proscribed would only take place in the day-to-day interaction among persons within Australia. ${ }^{160}$

\section{The Tasmanian Dam Case}

In 1983, the High Court, again by a four-to-three vote, handed down its decision in the Tasmanian Dam Case. ${ }^{161}$ That case involved actions stemming from a convention that Australia had ratified in 1974, the Convention for the Protection of the World Cultural and Natural Heritage. ${ }^{162}$ The object of the Convention was to establish "an effective system of collective protection of the cultural and natural heritage of outstanding universal value."163 Under the terms of the Convention, a World Heritage Committee was established. ${ }^{164}$ The Committee was to establish criteria for inclusion of properties on a World Heritage List and a List of World Heritage in Danger. ${ }^{165}$ States Parties were required to make contributions to a World Heritage Fund to finance assistance with respect to included (or potentially suitable) properties approved by the Committee. ${ }^{166}$

Various articles of the Convention established obligations on the part of States Parties, primarily to protect and conserve property designated as a natural heritage situated on its territory. ${ }^{167}$ The Australian National Parks and Wildlife Conservation Act $1975,{ }^{168}$ adopted pursuant to this Convention, authorized the Governor-General of Australia to "make regulations for and in relation to giving effect" to the Convention for the Protection of the World Cultural and Natural Heritage. ${ }^{169}$ In September of 1981, the Premier of the State of Tasmania wrote to Commonwealth Prime Minister Malcolm Fraser requesting that several national parks in Tasmania be nominated for inclusion on the World Heritage List, including the Gordon River-Below-Franklin Dam area. In April 1982, the Prime Minister submitted his nomination of these parks to the World Heritage Committee.

In June of that same year, a statute was enacted by the parliament of the State of Tasmania authorizing construction of a dam, a power generating sta-

160. See id. at $477-78$.

161. Commonwealth v. Tasmania, 46 Austl. L.R. 625 (1983).

162. Convention for the Protection of the World Cultural and Natural Heritage, done Nov. 23, 1972, 27 U.S.T. 37, T.I.A.S. No. 8226.

163. Id preamble.

164. Id. art. 8.

165. Id. art. 11(5).

166. Id. art. 16.

167. Under article 4, States Parties recognize a "duty of ensuring the identification, protection, conservation, presentation and transmission to future generations of the cultural and natural heritage [as defined by articles $I$ and 2] and situated on its territory . . ." Article 5 provides that each State Party "shall endeavor, in so far as possible, and as appropriate for each country" to take specified measures in pursuit of that duty. Under article 6, States Parties "undertake . . to give their help in the identification, protection, conservation and preservation of . . . cultural and natural heritage ... [and] not to take any deliberate measures which might damage [it] directly or indirectly ...."

168. National Parks and Wildlife Conservation Act 1975, 1975 Austl. Acts 103.

169. Id. § 69, 1975 Austl. Acts at 128. 
tion, and other associated works on the Gordon River. ${ }^{170}$ At the time that the authorization was adopted, the Premier of Tasmania (not the same Premier who recommended that the area be listed as one of the World Heritage areas) requested that Prime Minister Fraser withdraw the World Heritage nomination. Despite the fact that Fraser refused to withdraw the nomination, construction on the dam began. Areas of land were excised from the FranklinLower Gordon Wild Rivers National Park by the state and vested in the Hydro-Electric Commission of Tasmania.

In December 1982, the World Heritage Committee, listing the three parks as natural heritages, expressed concern at the possible destruction of national and cultural features in the region as a result of the dam project. Extensive flooding of both wilderness land and archeological sites was feared. The Committee suggested that the property be placed on the World Heritage in Danger list until the question of the construction of the dam was resolved.

When the Labor Party came to power in March 1983, it proceeded to enact legislation and regulations with respect to the dam, putting the Commonwealth in direct confrontation with the State of Tasmania. One regulation, pursuant to section 69 of the 1975 Act, forbade inter alia "construction of a dam or associated works [or] . . . any act in the course of, or for the purpose of," such construction; excavation; erection of buildings "or other substantial structure[s];" killing or damaging any trees; or "carry[ing] out any other works" without the consent of a Commonwealth Minister. ${ }^{171}$ The second section of that regulation went further and forbade any act "that is likely adversely to affect the conservation or preservation of that area as part of the world cultural heritage or natural heritage."172 A 1983 Commonwealth statute ${ }^{173}$ identified specific properties, including the Franklin Dam area, as subject to essentially the same prohibitions, noting that protection or conservation of the properties was "a matter of international obligation"; "necessary or desirable for the purpose of giving effect to a treaty . . . or obtaining for Australia any . . . benefit under a treaty"; and "a matter of international concern (whether or not it is also a matter of domestic concern)," because failure to conserve or protect "would, or would be likely to, prejudice Australia's relations with other countries." 174

The State of Tasmania challenged both the regulations and the Act as ultra vires and invalid. The validity of the regulations depended upon whether section 69 of the 1975 Act was valid as an exercise of the external affairs power and whether the regulations themselves were "regulations for and in relation to giving effect to the Convention." 175 The validity of sections 6 and 9 of the

170. Gordon River Hydro-Electric Power Development Act 1982, 1982 [Pt. l] Tasm. Sess. Stat. 3.

171. Regulation 5(1), World Heritage (Western Tasmania Wilderness) Regulations (modified March 1983), cited in The Tasmanian Dam Case, 46 Austr. L.R. at 640-41.

172. Id. Regulation 5(2), cited in The Tasmanian Dam Case, 46 Austl. L.R. at 641.

173. World Heritage Properties Conservation Act 1983, 1983 Austl. Acts - (unavailable at publication).

174. See id. $\S \S 6,9$.

175. The Tasmanian Dam Case, 46 Austl. L.R. at 675. 
1983 Act also depended upon whether they were valid exercises of the external affairs power. ${ }^{176}$

The High Court upheld section 69 of the 1975 Act by a four-to-three vote, but it found the regulations invalid. A four-person majority also upheld section 6 and part of section 9 of the 1983 Commonwealth Act, as well as the regulations and proclamations made in accordance with those sections, although the remainder of section 9 was found to be invalid. The net result was to support the exercise of Commonwealth power over the State of Tasmania as within the external affairs power of section 51 (xxix), permitting the prohibition of the dam project despite state legislation authorizing the construction of the dam.

The four-person majority included three members of the Koowarta v. BjelkePetersen ${ }^{177}$ majority: Justices Mason, Murphy, and Brennan. They were joined by Justice Deane. ${ }^{178}$ All of the justices in the majority were in agreement that the existence of an international agreement on any subject matter supports implementing laws, and that there is virtually no limit to the range of possible subject matter. Thus, in the majority view, the section 51 (xxix) power is, in effect, coextensive with the executive treatymaking power as implemented by the Parliament of the Commonwealth, subject only to a limited number of express prohibitions contained elsewhere in the constitution. The mere fact that the power was one generally reserved to the states would not prevent the Commonwealth from enacting legislation concerning that subject matter area.

Justice Mason's opinion ${ }^{179}$ asserted that all that is required to justify legislation under the external affairs power is mutuality of interest between international parties or some benefit resulting from observance of the treaty. The Court had to defer to Parliament on this issue. Because the law in question was directed to the protection and conservation of the region, it was valid even though its "impact on Tasmania's capacity to control development is severe." 180 Justice Murphy agreed with Justice Mason and added that it was the electorate, not the Court, that should control any exercise of power in this regard. ${ }^{181}$ If a matter was one of international concern, that fact alone would bring it within the definition of "external affairs." 182

Justice Brennan's opinion ${ }^{183}$ was not quite so broad. If a treaty did not clearly impose an obligation, to justify Commonwealth legislation it must at least evidence international concern over its subject matter. That is, the sub-

176. Tasmania raised several other arguments under various provisions of the constitution that are not discussed in this article.

177. 39 Austl. L.R. 417 (1982); see supra notes $125-60$ and accompanying text.

178. Justice Stephen had left the High Court to become Australia's Governor-General in 1982.

179. The Tasmanian Dam Case, 46 Austl. L.R. at 688-720.

180. Id. at 702. The case came at a time of economic recession in Australia, felt most acutely in Tasmania. The Franklin River Dam was seen as a way of reducing the cost of power and employing vast numbers of people in its building and related industries. Thus it was thought that this decision's economic impact on Tasmania would be severe.

181. Id. at 728 .

182. See id. at 729-30.

183. Id. at $760-97$. 
ject must affect or be likely to affect Australia's relations with international persons. ${ }^{184}$ Implementing laws must actually be conducive to the international convention, however. ${ }^{185}$ When the convention permits discretion, the test for the Court would be whether any part of the implementing law is not reasonably considered as appropriate to the treaty's goals. ${ }^{186}$ Here, of course, Justice Brennan felt that the Commonwealth act in question was appropriate.

Justice Deane, the new member of the majority, interpreted the external affairs power very broadly. ${ }^{187}$ In his view, "responsible conduct of external affairs . . . [requires] observance of the spirit as well as the letter of international agreements . . . [in] pursuit of international objectives which cannot be measured in terms of binding obligation." 188 A treaty with a broad purpose would permit wide discretion in implementing legislation. As long as the laws were reasonably appropriate to the purposes of such agreements, they should be upheld. ${ }^{189}$

As they had been in Koowarta, the dissenters were led by Chief Justice Gibbs. ${ }^{190}$ They emphasized that a majority of the Koowarta Court had rejected the notion that mere entry into a treaty will support the exercise of the section 51 (xxix) power. Because Justice Stephen's opinion in Koowarta had been the swing position, they contended that the High Court was required by notions of precedent to formulate and apply an acceptable articulation of the "international in character" criterion set forth in his opinion. ${ }^{191}$ The dissenters felt that the preservation and conservation of natural and cultural heritage were not nearly so important morally or politically as the elimination of racial discrimination, with which the Koowarta case had been concerned. ${ }^{192}$ Moreover, failure to meet the obligations of the Convention was not likely to affect Australia's relations with other nations. ${ }^{193}$ The dissenters also argued that the fact that the Convention vested so much discretion in States Parties to determine how they would perform was an indication that international concern was not that intense. ${ }^{194}$ Justice Gibbs interpreted Justice Stephen's position in the Koowarta case as requiring consideration of the degree to which a treaty affects Australia's relations with other nations and the extent to which it embodies international intentions to act. ${ }^{195}$ Finally, the Convention, in its operative articles, ${ }^{196}$ created no binding obligations; rather, it expressed a

184. Id. at 777. Justice Brennan said that in this case, unless Australia wished to "attribute hypocrisy and cynicism to the international community," such relations would indeed be affected.

185. Id. at 782 .

186. Id.

187. Id. at 798-834.

188. Id. at 805 .

189. See id. at 805-06.

190. Id. at 633-87.

191. See supra text accompanying notes $149-53$.

192. The Tasmanian Dam Case, 46 Austl. L.R. at 670.

193. Id. at 671 .

194. Id.

195. Id. at 670 .

196. Convention for the Protection of World Cultural and Natural Heritage, supra note 162, arts. 4.5. 
consensus as to aspirations. The dissenters argued that the earlier cases of The King v.Burgess ${ }^{197}$ and Airlines of N.S.W. Proprietary, Ltd. v. New South Wales 198 strongly suggest that if no obligation is imposed on the Commonwealth by the treaty, no obligations can be imposed on the states by the Commonwealth. ${ }^{199}$

Justice Gibbs went on to note that even if the treaty in this case were considered to represent an "external affair," the Commonwealth's implementing legislation did not give effect to the international convention, that is, it did not "perform the obligations or secure the benefits" that the international convention imposed or conferred. ${ }^{200}$ If there is no obligation created, the Commonwealth can only attempt to persuade the states to pursue the goals of the agreement. The Commonwealth, in his view, could not mandate protective measures such as these because they went beyond the terms of the agreement and were ultra vires under the Burgess case. ${ }^{201}$

All members of the court in the Tasmanian Dam Case purported to apply the "congruence" test. ${ }^{202}$ The difference in result on the question whether the legislation is congruent with the obligations of the treaty depends on how the "obligation" is characterized. The dissenting Justices, Gibbs, Wilson, and Dawson, recognized no obligation. ${ }^{203}$ Justices Deane and Brennan, two members of the majority, required some degree of closeness of fit between the obligation and the exercise of the section 51 (xxix) power. ${ }^{204}$ Justice Mason was satisfied that the obligation was that of instituting a "regime of control" with respect to protection and conservation of cultural and natural heritage and that all operative provisions were "appropriate and adapted to the desired end."205 Justice Murphy merely stated that the operative sections were "reasonably appropriate to implementation of the Convention."206

State officials and other commentators were highly critical of the Tasmanian Dam decision. Premier Gray of Tasmania said that "decisions which have such far-reaching effects on the constitution of this country should at least be decided unanimously by the High Court and not be a majority decision."207

197. 55 C.L.R. 608 (Austl. 1936); see supra text accompanying notes 111-17.

198. 113 C.L.R. 54 (Austl. 1965); see supra text accompanying notes 118-120.

199. The Tasmanian Dam Case, 46 Austl. L.R. at 671-75.

200. Id. at 671 .

201. In Airlines of N.S.W. Proprietary, Ltd., Chief Justice Barwick said, in an often-quoted passage: But where a law is to be justified under the external affairs power by reference to the existence of a treaty or a convention, the limits of the exercise of the power will be set by the terms of that treaty or convention, that is to say, the Commonwealth will be limited to making laws to perform the obligations, or to secure the benefits which the treaty imposes or confers on Australia. Whilst the choice of the legislative means by which the treaty or convention shall be implemented is for the legislative authority, it is for this Court to determine whether particular provisions, when challenged, are appropriate and adapted to that end. The Court will closely scrutinize the challenged provisions to ensure that what is proposed to be done substantially falls within the power.

113 C.L.R. at 86.

202. See id.

203. The Tasmanian Dam Case, 46 Austl. L.R. at 674, 745-49, 849.

204. Id. at 770-72, 801-06

205. Id. at 702-03.

206. Id. at 736 .

207. The Weekend Australian, July 2-3, 1983, at 1 . 
Premier Bjelke-Petersen of Queensland stated that the decision marked "the end of Federation and shows the first crack in the Commonwealth." 208 Another Queensland politician was quoted as saying that "the rights of each state are imperilled if the Commonwealth uses its UN treaties as a stick with which to beat the states into submission." 209 A Queensland legal expert said "the States are now virtually subject to the whim of Canberra, which can make international agreements and bind itself to overrule the States."210 One newspaper editorial commented that "the judgment has created the most fundamental constitutional change since Federation, in a way that was probably never envisaged by its founders." 211 Another editorial noted that "control over the basic principles of Australia's system of government has been taken out of the hands of the people and delivered to judges not answerable to any electorate," and that the federal government's "legal victory has saved a river but has sacrificed one of the safeguards of our democratic system."212 A Liberal Party spokesman said that the decision would have such a "profound effect on the division of powers between the Commonwealth and the States . . . that the system as we have known it could virtually cease to exist." 213

\section{The External Affairs Power After the Tasmanian Dam Case}

The decision in the Tasmanian Dam Case supports the broader view of the external affairs power: Parliament can implement any treaty made by the Commonwealth, no matter what its subject matter, provided it does not contravene a specific constitutional prohibition and is not a treaty artifically entered into in order to usurp legislative power for the Commonwealth that otherwise had not been given it. The decision rejects the narrow view that some limitation must be placed on the Commonwealth's power to implement treaties in order to maintain the careful balance between state and Commonwealth powers incorporated in the constitution. The dissenting view, that Parliament's power is confined to implementing treaties truly international in character, was also rejected.

Although the broad, expansive view of the section 51 (xxix) power prevails, even some members of the Tasmanian Dam majority emphasized that the legislation in question must be clearly designed to implement the treaty. Whether the test articulated by some, that the legislation be "reasonably appropriate" to implementing the treaty or convention, is so broad as to impose virtually no limit on legislation, remains to be seen. At least the High Court, in both Koowarta v. Bjelke-Petersen ${ }^{214}$ and the Tasmanian Dam Case, has upheld use of the external affairs power to reach subjects normally reserved to the states by the

208. Id. at 8 , col. 2 .

209. Id. at 8 , col. 3 .

210. Id. at 1 .

211. Id. at 10 , cols. 1-2.

212. The Australian, July 7,1983 , at I, cols. 2-3.

213. Statement of Senator Peter Durack, quoted in The Weekend Australian, July 2-3, 1983, at 1 (Senator Durack is the opposition's spokesman on attorney general matters.).

214. 39 Austl. L.R. 417 (1982); see supra notes 125-60 and accompanying text. 
constitution and tradition. Admittedly, however, the vote in each case was extremely close.

To what extent might future Commonwealth legislation on education be authorized by the external affairs power, particularly with regard to unfunded civil rights mandates like those of such U.S. statutes as Title VI of the Civil Rights Act of 1964, ${ }^{215}$ Title IX of the Education Amendments of 1972, ${ }^{216}$ and section 504 of the Rehabilitation Act of 1973?217 Justice Wilson, in his dissenting opinion in Koowarta, expressed concern that the emerging "sophisticated network of international arrangements directed to the personal, economic, social and cultural development of all human beings," would mean that if section 51 (xxix) were interpreted as vesting Parliament with power in all of these areas, the effect "would be to transfer to the Commonwealth virtually unlimited power in almost every conceivable aspect of life in Australia, including . . . education."218 Justice Gibbs also was concerned that if section 51 (xxix) were interpreted to empower Parliament to make laws to carry into effect within Australia "any treaty which the Governor-General may make," Parliament would, in effect, be empowered to make laws on any subject, thus destroying the federal balance achieved by the constitution. ${ }^{219}$ "[The executive] could, for example, by making an appropriate treaty, obtain for the Parliament powers to control education, to regulate the use of land, to fix the conditions of trading and employment, to censor the press or to determine the basis of criminal responsibility." 220 Thus, at least two of the dissenters believed that the majority's opinion in Koowarta would give the Commonwealth power over education if it could be related to treaties, international agreements, or covenants.

\section{IV}

\section{The Effects of a Broad Interpretation of Sections 51 (xxix) and 96 on the Commonwealth's Role in Education}

\section{A. International Agreements to Which Australia is a Party}

One recent commentator has pointed out that education today clearly is an international concern, and he notes that many international organizations of which Australia is a member consider education to be an important objective

215. 42 U.S.C. $\S \S 2000 \mathrm{~d}$ to $2000 \mathrm{~d}-4$ (1982).

216. 20 U.S.C. $\S \S 1681-1686$ (1982).

217. 29 U.S.C. $\$ 794$ (1982). As previously noted, AustL. Const. \$ 96 permits the Commonwealth to provide financial assistance to any State on such terms and conditions as the Parliament thinks fit, and therefore might support a grant-in-aid statute for education with the kinds of conditions which are found, for example, in the Education for All Handicapped Children Act of 1975. See infra text accompanying notes 336-40. In addition, section 51(xxiii) gives Parliament the power "to make laws for the peace, order, and good government of the Commonwealth with respect to . . . [t]he provision of . . . benefits to students . . . "This section thus provides authorization for financial aid directly to students. It might also authorize a much broader exercise of power in the area of educational policy, although it has not been so interpreted to date.

218. Koowarta, 39 Austl. L.R. at 481 .

219. Id. at 438.

220. Id. (emphasis added). 
for them or even their principal focus. ${ }^{221}$ These organizations include the United Nations Organization, the United Nations Educational, Scientific, and Cultural Organization, the International Labor Organization, and the Organization for Economic Cooperation and Development. Moreover, Australia has participated in educational programs through its membership in the Commonwealth Education Conference, the Colombo Plan, the Southeast Asia Treaty Organization, and the Asian and Pacific Council. He argues that conventions signed or agreements made on issues involving education by Australia as a member of these international organizations would attract the operation of the external affairs power and thus permit the Commonwealth to enact legislation dealing with education. ${ }^{222}$

There are five major conventions or covenants which deal with education, at least in part. The first is the International Convention on the Elimination of All Forms of Racial Discrimination. ${ }^{223}$ This Convention was relied upon by Parliament when it enacted the Racial Discrimination Act 1975, ${ }^{224}$ challenged by the State of Queensland in Koowarta $v$. Bjelke-Petersen. ${ }^{225}$ In that Convention, the States Parties undertake to prohibit all forms of discrimination wherever found. Article 5, in particular, provides in part:

States Parties undertake to prohibit and eliminate racial discrimination in all its forms and to guarantee the right of everyone, without distinction as to race, colour or national or ethnic origin, to equality before the law, notably in the enjoyment of the following rights:

(e) Economic, social and cultural rights, in particular:

(v) The right to education and training; . . . 226

In article 6, the States Parties undertake to "assure . . . effective protection and remedies" against any violations of the Convention. ${ }^{227}$

The International Convention on the Elimination of All Forms of Discrimination Against Women 228 was adopted by the United Nations General Assembly in December 1979. Article 10 of that Convention reads:

States Parties shall take all appropriate measures to eliminate discrimination against

221. Birch, Education and the External Affairs Power: Implications for the Governance of Australian Schools, 27 Austl. J. Educ. 234, 240-42 (1983). Following Koowarta v.Bjelke-Petersen, 39 Austl. L.R. 417 (1982), see supra notes 125-60 and accompanying text, other authors also suggested that the Commonwealth could legislate in the field of human rights to implement international agreements, and that such legislation could override any state or Commonwealth laws that were inconsistent with human rights guarantees. See J. McMillan, G. Evans \& H. Storey, supra note 6, at 95.

222. Birch, supra note 221 , at 240 .

223. Supra note 127. The Convention was adopted by the General Assembly of the United Nations on December 21, 1965. Australia signed the Convention on October 13, 1966 and ratified it on September 30, 1975. The Convention entered into force January 4, 1969.

224. 1975 Austl. Acts 347.

225. 39 Austl. L.R. 417 (1982); see supra notes 125-60 and accompanying text.

226. International Convention on the Elimination of All Forms of Racial Discrimination, supra note 127 , art. 5 .

227. Id. art. 6.

228. Opened for signature March 1, 1980, G.A. Res. 180, 34 U.N. GAOR Supp. (No. 46) at 193, U.N. Doc. A/RES/34/180. The Convention was signed by Australia on July 17, 1980, and entered into force on September 3, 1981. 
women in order to ensure to them equal rights with men in the field of education and in particular to ensure, on a basis of equality of men and women:

(a) The same conditions for career and vocational guidance, for access to studies and for the achievement of diplomas in educational establishments of all categories .... ;

(b) Access to the same curricula, the same examinations, teaching staff with qualifications of the same standard and school premises and equipment of the same quality;

(c) The elimination of any stereotyped concept of the roles of men and women at all levels and in all forms of education . . . in particular, by the revision of textbooks and school programmes and the adaptation of teaching methods . . . ;

(e) The same opportunities for access to programmes of continuing education . . . ; ... (g) The same opportunities to participate actively in sports and physical education

In article 2, States Parties specifically undertake "to adopt appropriate legislative and other measures, including sanctions where appropriate, prohibiting all discrimination against women . ..."230 Finally, article 4 permits, but does not require, States Parties to adopt affirmative action measures to "accelerat[e] de facto equality between men and women."'231

The International Covenant on Economic, Social and Cultural Rights 232 specifically notes that States Parties "recognize the right of everyone to education."233 Article 2(2) notes that the States Parties undertake to guarantee that the rights in the Covenant, including the right to education, "will be exercised without discrimination of any kind as to race, colour, sex, language, religion, political or other opinion, national or social origin, property, birth or other status."234 In this Covenant, however, the obligations are not fully guaranteed immediately. Article 2(1) says that each State Party undertakes to take steps "to the maximum of its available resources, with a view to achieving progressively the full realization of the rights recognized in the present Covenant by all appropriate means, including particularly the adoption of legislative measures." 235 One might call this the "all deliberate speed" provision.

There is also an international agreement that is concerned solely with education. The United Nations Educational, Scientific, and Cultural Organization (UNESCO) adopted the Convention Against Discrimination in Education on December $14,1960 .^{236}$ The preamble to the Convention notes that UNESCO

229. Id. art. 10 .

230. Id. art. 2(b).

231. Id. art. $4(1)$.

232. Opened for signature Dec. 19, 1966, Annex to G.A. Res. 2200, 21 U.N. GAOR Supp. (No. 16) at 49, U.N. Doc. A/6316 (1966) (hereinafter cited as International Covenant on Economic, Social and Cultural Rights). The Covenant was adopted by the U.N. General Assembly on December 16, 1966; signed by Australia on December 18, 1972, and ratified on December 10, 1975; and entered into force on January 3, 1976.

233. Id. art. 13(1).

234. Id. art. 2(2).

235. Id. art. 2(1).

236. Annex I to U.N. Doc. E/CN.4/Sub.2/210 (1961) (hereinafter cited as Convention Against Discrimination in Education). The Convention was ratified by Australia in August 1974 and entered into force in November 1974. 
"has the duty not only to proscribe any form of discrimination in education but also to promote equality of opportunity and treatment for all in education "237 Article 1 of the Convention defines the term "discrimination" to include:

any distinction, exclusion, limitation or preference which, being based on race, colour, sex, language, religion, political or other opinion, national or social origin, economic condition or birth, has the purpose or effect of nullifying or impairing equality of treatment in education and in particular:

(a) Of depriving any person or group of persons of access to education of any type or at any level;

(b) Of limiting any person or group of persons to education of an inferior standard;

(c) Subject to the provisions of Article 2 of this Convention, of establishing or maintaining separate educational systems or institutions for persons or groups of persons; . . . .238

The establishment or the maintenance of separate educational systems or institutions on the basis of sex is permitted, however, "if these systems or institutions offer equivalent access to education, provide a teaching staff of qualifications of the same standard as well as school premises and equipment of the same quality, and afford the opportunity to take the same or equivalent courses of study.",239

Under this Convention, States Parties undertake to repeal statutory provisions or discontinue administrative practices that involve discrimination in education and "to ensure, by legislation where necessary, that there is no discrimination in the admission of pupils to educational institutions." 240 Furthermore, the States Parties undertake to "formulate, develop and apply a national policy which . . . will tend to promote equality of opportunity and of treatment in the matter of education . . . . "241

Finally, while the International Covenant on Civil and Political Rights ${ }^{242}$ does not specifically deal with education, it purports to protect individual civil and political rights, as well as economic, social and cultural rights. Article 26 of that Covenant provides:

All persons are equal before the law and are entitled without any discrimination to the equal protection of the law. In this respect, the law shall prohibit any discrimination and guarantee to all persons equal and effective protection against discrimination on any ground such as race, colour, sex, language, religion, political or other opinion, national or social origin, property, birth or other status. ${ }^{243}$

237. Id. preamble.

238. Id. art. 1 .

239. Id. art. 2(a). Article 2 also permits separate schools for "religious or linguistic reasons," as long as attendance at such institutions is optional, id. art. 2(b), and the establishment or maintenance of private educational institutions as long as the purpose "is not to secure the exclusion of any group," id. art. 2(c).

240. Id. art. 3(a)-(b).

241. Id. art. 4.

242. Supra note 108. The Covenant was adopted by the General Assembly of the United Nations on Dec. 16, 1966; signed by Australia on December 18, 1972, and ratified on August 13, 1980; and entered into force on March 23, 1976. The latter date does not apply to article 41 , which entered into force on March 28, 1979.

243. Id. art 26 . 
A State Party undertakes "to take the necessary steps, in accordance with its constitutional processes . . . to adopt such legislative or other measures as may be necessary to give effect to the rights recognized in the . . . Covenant."244 In addition, States Parties must provide effective remedies to any person whose rights or freedoms recognized in the Covenant are violated. ${ }^{245}$ The provisions of the Covenant apply to "all parts of federal states" as well as to nations. ${ }^{246}$ Australia signed the treaty with reservations, ${ }^{247}$ including one which related to this last provision. The reservation indicated that implementation of the provisions of the Covenant which were the responsibility of the federal authorities, as assigned by Australia's constitution, was to be a matter for those authorities, but that implementation of those provisions of the Covenant over whose subject matter the states were assigned authority by the constitution would be a matter for the states. ${ }^{248}$ This reservation also applied to the adoption of legislation to give effect to the rights recognized in the Covenant. ${ }^{249}$

The question of the significance of Australia's reservation to the Covenant would appear to be mooted by the current state of section 51 (xxix) doctrine. The effect of the reservation, if valid, was to leave implementation of the Covenant with respect to matters of state law to the states. The effect of Koowarta v. Bjelke-Petersen ${ }^{250}$ and the Tasmanian Dam Case, ${ }^{251}$ however, is to make the subject matter of any treaty to which Australia is a signatory a matter for Com-

244. Id. art. 2(2).

245. Id. art. 2(3).

246. Id. art. 50.

247. A reservation is "a unilateral statement, however phrased or named, made by a State, when signing, ratifying, accepting, approving or acceding to a treaty, whereby it purports to exclude or modify the legal effect of certain provisions of the treaty in their application to that State. . . ." Vienna Convention on the Law of Treaties, art. 2(1)(d), opened for signature May 23, 1969, U.N. Doc. A/CONF. 39/27/Corr. 1, reprinted in 63 AM. J. INT'L L. 875 (1969); see Triggs, Australia's Ratification of the International Covenant on Civil and Political Rights: Endorsement or Repudiation?, 31 INT'L \& CoMP. L. Q. 278, 280-84 (1982). A reservation to a multilateral treaty becomes effective when another state accepts it. Vienna Convention on the Law of Treaties, supra, art. 20(4)(a). Failure to object to a reservation within twelve months of notification waives any rights to object to the legal effects it creates. Id. art. 20(5). A reservation may be invalid per se, however, if it is found to be "incompatible with the object and purpose of the treaty." Triggs, supra, at 283 . There exist no reliable criteria for resolving this question but authorities have isolated several factors which guide the inquiry. See id. at 284 \& nn.31-32.

248. The reservation specifically states:

Australia advises that, the people having united as one people in a Federal Commonwealth under the Crown, it has a federal constitutional system . . . . It enters a general reservation that article 2, paragraphs 2 and 3 , and article 50 shall be given effect consistently with and subject to the provisions in article 2, paragraph 2.

In particular, in relation to the Australian States the implementation of those provisions of the Covenant over whose subject matter the federal authorities exercise legislative, executive and judicial jurisdiction will be a matter for those authorities; and the implementation of those provisions of the Covenant over whose subject matter the authorities of the constituent States exercise legislative, executive and judicial jurisdiction will be a matter for those authorities; and where a provision has both federal and State aspects, its implementation will accordingly be a matter for the respective constitutionally appropriate authorities . . . .

Iultilateral Treaties Deposited with the Secretary-General 118, U.N. Doc. St/LEG/SER.E/ (1982).

249. See supra text accompanying note 244 .

250. 39 Austl. L.R. 417 (1982); see supra notes 125-60 and accompanying text. 
monwealth legislative power, even if the subject matter was otherwise constitutionally committed to the states.

\section{B. The Significance of These Agreements for Civil Rights Mandates}

The question now to be explored is whether the foregoing covenants and conventions, when coupled with the external affairs power of section 51 (xxix), provide the Commonwealth with the authority to enact civil rights laws similar in nature to Title VI of the Civil Rights Act of $1964,{ }^{252}$ Title IX of the Education Amendments of 1972,253 section 504 of the Rehabilitation Act of 1973, ${ }^{254}$ and their implementing regulations.

The broad language of each of the convenants and conventions discussed above, together with the expansive reading given to the section 51 (xxix) power by the majority in both Koowarta and the Tasmanian Dam Case, arguably gives the Commonwealth authority to pass legislation similar to Title VI. Article 5 of the International Convention on the Elimination of All Forms of Racial Discrimination ${ }^{255}$ and article 2(2) of the International Covenant on Economic, Social and Cultural Rights ${ }^{256}$ would seem to provide such authority. Even the International Covenant on Civil and Political Rights, although it does not specifically mention education, in providing for "equal protection of the law" in article $26^{257}$ would seem to authorize legislation comparable to Title VI.

The broad view of the external affairs power taken by the Koowarta and Tasmanian Dam cases ${ }^{258}$ - that the existence of an international agreement on virtually any subject will support Commonwealth legislation implementing the obligations of the agreement ${ }^{259}$-would permit legislation related to the above-mentioned Conventions. The second question, whether legislation patterned after Title VI would be congruent with the obligations of the international agreements, ${ }^{260}$ also should be answered in the affirmative in view of the majority position that laws and regulations need only be reasonably related to accomplishing the obligation undertaken in the agreement. ${ }^{261}$

251. Commonwealth v. Tasmania, 46 Austl. L.R. 625 (1983); see supra notes 161-213 and accompanying text.

252. "No person in the United States shall, on the ground of race, color, or national origin, be excluded from participation in, be denied the benefits of, or be subjected to discrimination under any program or activity receiving Federal financial assistance." 42 U.S.C. $\$ 2000 \mathrm{~d}$ (1982); see also id. $\S \S 2000 \mathrm{~d}-1$ to $2000 \mathrm{~d}-5$.

253. "No person in the United States shall, on the basis of sex, be excluded from participation in, be denied the benefits of, or be subjected to discrimination under any education program or activity receiving Federal financial assistance...." 20 U.S.C. \$1681(a) (1982).

254. "No otherwise qualified handicapped individual . . . shall, solely by reason of his handicap, be excluded from participation in, be denied the benefits of, or be subjected to discrimination under any program or activity receiving Federal financial assistance." 29 U.S.C. $\$ 794$ (1982).

255. See supra text accompanying notes 223-26.

256. See supra text accompanying note 234.

257. See supra text accompanying notes 242-43.

258. See supra section III D.

259. See supra text accompanying notes 179-89.

260. See supra text accompanying note 117 .

261. While two members of the majority in the Tasmanian Dam Case, Justices Deane and 
The "all deliberate speed" provision ${ }^{262}$ in the International Covenant on Economic, Social and Cultural Rights permits the argument to be made that equality of education is aspirational only, and thus not of sufficient international concern to permit Commonwealth legislation in an area committed to the states. This kind of argument clearly failed in the Tasmanian Dam Case, however. ${ }^{263}$

One of the interesting questions is whether the terms "national or ethnic origin" in the Convention on the Elimination of All Forms of Racial Discrimination, ${ }^{264}$ and "language" and "national origin" in the Covenant on Civil and Political Rights, ${ }^{265}$ the Covenant on Economic, Social and Cultural Rights, ${ }^{266}$ and the Convention Against Discrimination in Education ${ }^{267}$ would be interpreted in the same manner as the term "national origin" in Title VI ${ }^{268}$ has been interpreted. The U.S. Department of Education, following policy originally established by the Department of Health, Education and Welfare (HEW), has interpreted this language to require affirmative assistance to children with limited English proficiency. ${ }^{269}$ This interpretation was upheld by the Supreme Court in Lau v. Nichols. ${ }^{270}$ At one point, the Department of Education went so far as to promulgate regulations that interpreted affirmative assistance to require, in certain circumstances, the provision of bilingual education. ${ }^{271}$ Failure to do so would be a violation of Title VI. ${ }^{272}$ Similar interpretation in Australia of the relevant provisions of these conventions and covenants could permit the Commonwealth to view failure on the part of school authorities to provide affirmative assistance (including bilingual education) to language minority children as discrimination on the basis of "language," "ethnic origin," or "national origin."

Looking at the language of the Convention on the Elimination of All Forms of Discrimination Against Women, it is not unlikely that a majority of

\footnotetext{
Brennan, would require some degree of closeness of fit between the obligation and the implementing legislation, 46 Austl. L.R. at 770-72, 801-06; see supra text accompanying notes 202-04, Title VI-type legislation would clearly pass the test. Justices Murphy and Mason would require only that the legislation be "reasonably appropriate." 46 Austl. L.R. at 702-03, 736; see supra text accompanying notes 205-06.
}

262. See supra text accompanying note 235 .

263. See supra text accompanying notes 191-99.

264. International Convention on The Elimination of All Forms of Racial Discrimination, supra note 127 , art. $1(1)$. 2(1).

265. United Nations International Covenant on Civil and Political Rights, supra note 108, art

266. International Covenant on Economic, Social and Cultural Rights, supra note 232, art. 2(2).

267. Convention Against Discrimination in Education, supra note 236, art. 1.

268. 42 U.S.C. \& 2000d (1982).

269. See 35 Fed. Reg. 11,595 (1970).

270. 414 U.S. 563 (1974).

271. Proposed Rules (Nondiscrimination Under Programs Receiving Federal Assistance Through the Department of Education), 45 Fed. Reg. 52,052, 52,055-59 (1980) (proposed Aug. 5, 1980).

272. Id. The regulations did not become final, however. See Levin, An Analysis of the Federal Attempt to Regulate Bilingual Education: Protecting Civil Rights or Controlling Curriculum?, 12 J.L. \& Educ. 29 (1983). 
the High Court would also find legislation similar to Title IX ${ }^{273}$ to be congruent with the obligation undertaken by Australia as one of the States Parties. This conclusion would apply as well to the other three conventions and covenants which bar discrimination on the basis of sex. ${ }^{274}$

Article $10(\mathrm{c})$ of the Convention, ${ }^{275}$ promoting elimination of gender stereotypes through revision of textbooks and teaching methods, raises an interesting question. In drafting regulations to implement Title IX, HEW took the position that it would exclude textbooks and curricular content from the scope of administrative purview, ${ }^{276}$ out of concern that federal intervention in such matters "would thrust the Department into the role of Federal censor" and might possibly violate the first amendment. ${ }^{277}$ Since Australia does not have a constitutional equivalent to the U.S. Constitution's first amendment, there might be no equivalent difficulty for the Commonwealth in introducing a legislative or regulatory provision dealing with the subject matter of article $10(c)$ of the Convention.

The real question is whether legislation similar to section 504 of the Rehabilitation Act could be enacted in Australia under any of these covenants or conventions. Would either the term "birth" or the term "other status" be considered broad enough to include the handicapped as a protected group? Nowhere else in the covenants and conventions are the handicapped specifically mentioned. In both the Covenant on Civil and Political Rights and the Covenant on Economic, Social and Cultural Rights, discrimination on the ground of "birth or other status" is prohibited.278 The Convention Against Discrimination in Education prohibits discrimination on the ground of "birth."279 However, the term "other status" is not included in that Convention, and it is by no means evident that discrimination against the handicapped was meant to be included. ${ }^{280}$

273. Title IX has some of the same exceptions as the Convention: in regard to admissions, elementary and secondary schools, whether public or private, are exempt as are private institutions of undergraduate higher education and public institutions of undergraduate higher education that have traditionally been single-sex; military institutions are exempt; and religious institutions are exempt if Title IX would be inconsistent with their religious tenets. 20 U.S.C. \$ 1681 (1982).

274. International Covenant on Economic, Social and Cultural Rights, supra note 232; Convention Against Discrimination in Education, supra note 236; International Covenant on Civil and Political Rights, supra note 108 .

275. See supra text accompanying note 228.

276. 34 C.F.R. $\$ 106.42$ (1984).

277. 40 Fed. Reg. 24,135 (1975).

278. International Covenant on Civil and Political Rights, supra note 108, art. 2(1); International Covenant on Economic, Social and Cultural Rights, supra note 232, art. 2(2).

279. Convention Against Discrimination in Education, supra note 236, art. 1.

280. There are several U.N. General Assembly declarations which touch on issues of educational opportunity for the handicapped. One is the Declaration of the Rights of the Child, G.A. Res. 1386, 14 U.N. GAOR Supp. (No. 16) at 19, U.N. Doc. A/4354 (1959). Principle 5 of the Declaration states that " $[t]$ he child who is physically, mentally or socially handicapped shall be given the special ... education ... required by his particular condition." The second is the Declaration on the Rights of Mentally Retarded Persons, G.A. Res. 2856, 26 U.N. GAOR Supp. (No. 29) at 93, U.N. Doc. A/8588 (1971). It "calls for national and international action" to ensure that the Declaration will be a "frame of reference" for the protection of several listed rights, including "a right . . . to such education, training, rehabilitation and guidance as will enable him to develop his ability and maximum potential." The third is the Declaration on the Rights of Disabled Persons, G.A. Res. 3447, 30 
The remaining issue for a Commonwealth Parliament wishing to enact civil rights mandates in education under its section 51 (xxix) power is that of enforcement. In the United States, Title VI, Title IX, and section 504 are all enforced by the termination of federal funds going to any "program or activity" in which discrimination occurs. The phrase "program or activity" has recently been given a narrow interpretation by the U.S. Supreme Court. ${ }^{281}$ An expansive interpretation in Australia could have an overwhelming impact, particularly if not only the specific purpose grants but also the revenue sharing or tax reimbursement grants are considered to be federal or Commonwealth funds which can be cut off if discrimination occurs.

\section{Section 96 Authority}

As noted above, the international covenants and conventions discussed in this section do not provide clear and convincing support for equal educational opportunity for the handicapped. Thus a statute similar to U.S. section 504 might not be found to be within the Commonwealth's section 51 (xxix) power. Similarly, it is not clear that an affirmative duty to provide special assistance to the economically disadvantaged could be based on any of the agreements, although the Covenant on Civil and Political Rights and the Covenant on Economic, Social and Cultural Rights prohibit discrimination on the basis of "social origin,",282 and the Convention Against Discrimination in Education prohibits discrimination on the basis of "social origin" and "economic condition."283 Nevertheless, grant-in-aid statutes could contain conditions, similar to those found in the Education for All Handicapped Children Act ${ }^{284}$ and in Title I (now Chapter 1) of the Elementary and Secondary Education Act of $1965,{ }^{285}$ designed to ensure benefits to the economically disadvantaged.

The authority, in other words, need not lie in international conventions or covenants, coupled with the exercise of section 51 (xxix) power, but in a broader application of section 96 than has hitherto been followed. The question here would be whether section 96 could be read that expansively. The role that section 96 power played in enabling the Commonwealth to introduce

U.N. GAOR Supp. (No. 34) at 88, U.N. Doc. A/10284/Add.I (1975). It is similar to the Declaration on the Rights of Mentally Retarded Persons, and includes "the right to . . . education, vocational training and rehabilitation, aid, counseling . . . and other services which will enable them to develop their capabilities and skills to the maximum and will hasten the process of their social integration or reintegration." Such Declarations do not ordinarily carry the same weight as international treaties or agreements. As discussed above, see supra text accompanying notes 140-41, only two High Court Justices, Murphy and Mason, might find that the existence of a treaty is not a necessary prerequisite to the exercise of the section 51 (xxix) power. For them, it is sufficient that the legislation relate to a matter of international "concern" or to "observance in Australia of international standards of human rights," Koowarta v. Bjelke-Petersen, 39 Austl. L.R. 417, 473 (1982) (Murphy, J.), even if there is no international agreement.

281. Grove City College v. Bell, 104 S. Ct. 1211 (1984).

282. International Covenant on Civil and Political Rights, supra note 108, art. 2(1); International Covenant on Economic, Social and Cultural Rights, supra note 232, art. 2(2).

283. Convention Against Discrimination in Education, supra note 236, art. 1 .

284. 20 U.S.C. \& 1412 (1982).

285. 20 U.S.C. $\S 236$ (1982). 
and carry out the Uniform Tax Scheme has already been outlined.286 Although the section $\mathbf{8 1}$ power to appropriate money for "the purposes of the Commonwealth" has been used from time to time, it has not been a broadly used power and so the primary vehicle for the distribution of federal funds has been, and continues to be, section 96.287

As has been previously pointed out, section 96 grants can be made without any conditions at all. These are the general revenue grants made under the tax reimbursement or financial assistance grants programs in accordance with the 1942 Uniform Tax Scheme. The only "condition" presently imposed on these programs is that the States refrain from imposing their own income taxes. There are also specific purpose grants, which are made with specific conditions attached. Conditional grants are made in areas where the Commonwealth does not normally have legislative power, as illustrated by the States Grants (Schools) Act. ${ }^{288}$ Most commentators believe that section 96 can be construed to permit the Commonwealth to grant financial assistance to any state on such terms and conditions as it sees fit. ${ }^{289}$

In 1926, the High Court was presented with a case challenging the constitutionality of the Federal Aid Roads Act of 1926. ${ }^{290}$ This was "[ $\left.t\right]$ he first specific purpose grant enacted in Australia for a purpose not within the Commonwealth legislative power." 291 Under this Act, the Commonwealth was to enter into agreements with the various states, and provide funds to the states, based on these agreements, to enable them to construct and maintain roads. It was argued on behalf of the States of Victoria and South Australia that the law was invalid because it was a law relating to roadmaking rather than a law for granting financial aid to the states. Thus, it was not authorized under either section 96 or section 51 of the constitution. The States argued that, under section 96, Parliament could not attach as conditions to its grant any conditions which were, in effect, the exercise of legislative power not within section 51. In this case, since the principal purpose of the Act was road construction, it was not authorized by section 96 . Indeed, the plaintiffs went so far as to argue that section 96 applied only to loans for temporary purposes and that grant conditions could only be those of a kind customarily imposed to secure repayment of such loans.

The High Court, in what must be one of its briefest opinions, said simply that the Federal Aid Roads Act was a valid enactment, "plainly warranted by the provisions of Section 96 of the Constitution," and proceeded to dimiss the action. ${ }^{292}$

286. See supra text accompanying notes 54-56.

287. See J. McMillan, G. Evans \& H. Storey, supra note 6, at 84, 117.

288. 1973 Austl. Acts 1407; see supra text accompanying notes 96-98.

289. See, e.g., J. MCMillan, G. Evans \& H. Storey, supra note 6, at 120.

290. Victoria v. Commonwealth (The Federal Roads Case), 38 C.L.R. 399 (Austl. 1926) (per curiam).

291. Saunders, The Development of the Commonwealth Spending Power, 11 MeLb. U.L. Rev. 369, 386

292. The Federal Roads Case, 38 C.L.R. at 406. 
Section 81 of the Australian Constitution authorizes the legislature to appropriate funds for "the purposes of the Commonwealth," and it is generally accepted that this power extends to the making of grants to the States. There is still some doubt whether the phrase "purposes of the Commonwealth" is limited to those matters over which the Commonwealth Parliament has legislative or executive power under the constitution (primarily those powers given to it in section 51). ${ }^{293}$ Limitations on the scope of the appropriations power, however, have not acted as a constraint on grants to the states, inasmuch as the Commonwealth Parliament can use the grants power in section 96 . The section 96 power has been interpreted, however, as requiring that the grants be made through the state governments rather than directly by the Commonwealth. ${ }^{294}$

It was not until the Labor Party gained power in 1972 that resort to conditional grants under section 96 of the constitution was extensively used to implement policies in areas that went beyond the legislative powers given to the Commonwealth by the constitution. Prime Minister Whitlam said that the Commonwealth would be expected

to be involved in the planning of the function in which we are financially involved. We believe that it would be irresponsible for the national Government to content itself with simply providing funds without being involved in the process by which priorities are met, and by which expenditures are planned and by which standards are met. ${ }^{295}$

Expansion through the use of the section 96 power into many areas, including education, was slowed by the change of government following the December 1975 elections. The Liberal-Country Party indicated that it would end the specific purpose grants under section 96 and transfer the funds now going to such programs to general purpose revenue reimbursement. In a comment reminiscent of those of the present U.S. administration (and also the Nixon administration), Prime Minister Fraser, shortly after the elections, said:

[T] here are some programs . . . which represent areas of expenditure which clearly deserve continuing Commonwealth support but in which there is no obvious need that my Government can see for the Commonwealth to be involved in a specific way. There are matters in respect of which priorities should appropriately be left to the States and their authorities to determine.

In such cases, some form of absorption of specific purpose funds into general purpose funds would be appropriate. ${ }^{296}$

Despite such rhetoric, the number of specific purpose grants did not significantly diminish after the 1975 elections. Certainly grants for education continued and were even expanded to cover additional specific purposes. ${ }^{297}$

293. Else-Mitchell, The Australia Federal Grants System and Its Impact on Fiscal Relations of the Federal Government with State and Local Government, 54 AustL. L.J. 480, 481 (1980).

294. Id.

295. Id. at 484.

296. Id. at 485 .

297. For examples of specific purpose grants under the States Grants (Schools) Act 1973, 1973 Austl. Acts 1407, see supra text accompanying notes 96-98. 
The Federal Roads Case ${ }^{298}$ and subsequent statutes enacted by both political parties indicate that specific purpose grants can be enacted in Australia for purposes not otherwise within the legislative power of the Commonwealth under the authority of section 96 . The question, then, is whether anything in section 96 or elsewhere limits the extent or nature of the conditions the Commonwealth may attach to such grants. ${ }^{299}$

In upholding the validity of the Federal Aid Roads Act 1926, the High Court rejected the argument that the terms and conditions attached to a grant pursuant to section 96 must be restricted to financial terms and conditions "analogous to the terms and conditions of a mortgage, which are imposed to secure repayment of the loan." 300 The conditions attached to the grants in that statute were clearly regulatory conditions, specifying, among other things, the types of roads to be built, details of construction, and standards for future road maintenance. The grants were also conditioned on the states' providing matching sums.

The scope of section 96 was further clarified by Deputy Federal Commissioner of Taxation v. W.R. Moran Proprietary, Ltd. ${ }^{301}$ which indicated that section 96 power is not necessarily restricted by other provisions of the constitution. Chief Justice Latham noted in that case that "the remedy for any abuse of the power conferred by Section 96 is political and not legal in character." 302 In light of these cases, as well as the Uniform Tax Cases, ${ }^{303}$ the broad extent of section 96 power seemed to be a settled matter.

Theoretically, it would seem that the Commonwealth Parliament has the same extensive power to condition grants under section 96 as the U.S. courts have held Congress to have under article I, section 8 , clause 1 of the U.S. Constitution. ${ }^{304}$ As we have already seen, however, the conditions actually imposed on specific purpose grants, in the States Grants (Schools) Act 1973 and subsequent annual appropriations acts, have been almost non-existent compared to those attached to U.S. grant-in-aid statutes. ${ }^{305}$

298. Victoria v. Commonwealth, 38 C.L.R. 399 (Austl. 1926); see supra text accompanying notes 290-92.

299. See supra note 72 , indicating that there are no significant limits on the nature and extent of the conditions that can be imposed on grants-in-aid statutes enacted under U.S. ConST. art. I, $§ 8, \mathrm{cl}$. 1.

300. The Federal Roads Case, 38 C.L.R. at 405. The argument was made on behalf of the state of South Australia. Id.

301. 61 C.L.R. 735 (Austl. 1939).

302. Id. at 764 .

303. South Australia v. Commonwealth (First Uniform Tax Case), 65 C.L.R. 373 (Austl. 1942); Victoria v. Commonwealth (Second Uniform Tax Case), 99 C.L.R. 575 (Austl. 1957). See supra note 56 .

One recent commentator has noted that, in view of this series of cases, "[i]t is now settled that the nature and extent of the conditions attached to grants depend solely on political rather than legal considerations. In the case of specific purpose grants the most relevant political consideration is the philosophy of the current federal government." Saunders, supra note 291, at 395.

304. See supra notes 70-72 and accompanying text.

305. See supra text accompanying note 98 . 


\section{Australia's Current Educational Grant Programs Under SECTION 96}

\section{A. Language Minority Programs}

The principal grant-in-aid program for language minority children in the United States is the Bilingual Education Act, ${ }^{306}$ passed in 1968 as part of the amendments to the Elementary and Secondary Education Act. Under the original statute, a limited amount of funding was made available to school districts which submitted proposals. Among the programs to be funded were "bilingual education programs" and "programs designed to impart to students a knowledge of the history and culture associated with their languages." 307

In 1974, Congress amended the Act, ${ }^{308}$ noting that the purpose was "to encourage the establishment and operation, where appropriate, of educational programs using bilingual educational practices, techniques, and methods." 309 Bilingual education was defined as the giving of instruction in English "and to the extent necessary to allow a child to progress effectively through the educational system, the native language of the children of limited English-speaking ability." 310 The Bilingual Education Act provides fiscal incentives to school districts committed to assisting children with limited English proficiency, in contrast to the federal government's interpretation of Title VI of the Civil Rights Act of $1964^{311}$ as imposing an affirmative duty on school officials to provide special assistance to such children. Title VI, of course, does not provide any fiscal assistance, and the sanction for non-compliance with Title VI is the cutoff of all federal funds received by the school district.

Despite the discretionary nature of programs funded under the Bilingual Education Act, there are a number of conditions that clearly control what the schools may do if they receive the funds. For example, "to prevent the segregation of children on the basis of national origin" in programs supported under the Bilingual Education Act, "and in order to broaden the understanding of children about languages and cultural heritages other than their own, a program of bilingual instruction may include the participation of children whose language is English, but in no event shall the percentage of such children exceed 40 percent." 312 Moreover, in such courses as art, music, and physical education, children with limited proficiency in English must participate in regular classes rather than in separate classes. ${ }^{313}$ There are other con-

306. Bilingual Education Act, Pub. L. No. 90-247, $\S \S 701-706,81$ Stat. 783, $816-21$ (1968) (codified as amended at 20 U.S.C. $\$ \S 3381-3382,3384$ (1982)).

307. Id. § 704(c)(1)-(2), 81 Stat. at 817 (repealed 1972).

308. Bilingual Education Act, Pub. L. No. 93-380, tit. I, § 105(a)(l)-(b), 88 Stat. 484, 503-12 (1974) (codified as amended at 20 U.S.C. $\$ \S 3221-3261$ (1982)).

309. Id. $\S 702(\mathrm{a})(\mathrm{A}), 88$ Stat. at 503 (codified as amended at 20 U.S.C. $\S 3222(\mathrm{a})$ ).

310. Id. $\$ 703(4)(\mathrm{i}), 88$ Stat. at 504-05 (codified as amended at 20 U.S.C. $\$ 3223(\mathrm{a})(4)(\mathrm{A})(\mathrm{i}))$.

311. 42 U.S.C. $\S \S 2000 \mathrm{~d}$ to $2000 \mathrm{~d}-4$ (1982).

312. 20 U.S.C. $\$ 3223(\mathrm{a})(4)(\mathrm{B})$ (1982).

313. Id. §3223(a)(4)(C). 
ditions governing application for funds for a program of bilingual education, including limitations on what the funds can be used for and who may apply for the funds, a requirement that the proposal be developed in consultation with an advisory council of stipulated composition, and other criteria governing approval of the application. ${ }^{314}$ There are also detailed fiscal criteria to ensure that federal funds "supplement the level of State and local funds that, in the absence of those Federal funds, would have been expended for special programs for children of limited English proficiency and in no case to supplant such State and local funds."315 The regulations promulgated to implement this statute occupy fifty-nine pages in the Code of Federal Regulations.

As recently as 1978, nothing much had been done at the federal level in Australia either in English as a Second Language or in multicultural curricula. In 1978, a commission was established which then made recommendations to the Commonwealth government. As a result of these recommendations, the Schools Commission was authorized to make grants to the states for programs in these areas.

1. ESL Programs. In Australia, there are few conditions attached to funds for language minority children, and most of these are related to fiscal accounting. Grants for the English-as-a-Second-Language (ESL) Program had two elements in 1983. The larger share of funds was allocated for general support to government and nongovernment schools to provide services directed "at improving the English language competence of students from non-English-speaking backgrounds."'316 The States Grants (Schools Assistance) Act $1982^{317}$ requires only that the state ensure that the money be spent for that general purpose, that it submit a statement to the Commonwealth summarizing how the money was spent, and that it furnish the Commonwealth with a private accountant's certification that the funds have been spent as intended. ${ }^{318}$ There are no enforceable regulations implementing the statute. There are guidelines, but these merely suggest how the funds might be used:

- the employment of specialist teachers, including bilingual teachers, to teach English as a second language, and their use in a variety of situations, including, but not restricted to intensive and part-time withdrawal situations, and assistance to regular teachers to enable them to attend more adequately to English language development across the curriculum for second language learners;

- the employment of advisory staff, interpreters, translators, bilingual welfare officers, teacher aides and school-community liaison workers; and

- curriculum development and the provision of learning materials. ${ }^{319}$

314. See id. $\$ 3223(\mathrm{a})(4)(\mathrm{E}), 3231$.

315. Id. $\$ 3231(\mathrm{~b})(3)(\mathrm{G})$.

316. Commonwealth Schools Commission, Program Guidelines 1983, at 39 (1983) [hereinafter cited as GuideLiNes]. The total amount available was $\$ 55,377,000$, with $\$ 16,463,000$ of that amount going to nongovernment (including sectarian) schools. Id. at 41 . (The amounts are given in Australian dollars.)

317. 1982 Austl. Acts 1745.

318. See id. § 17, 1982 Austl. Acts at 1765.

319. GUIDELINES, supra note $316, \S 6.5$, at $39-40$. 
The remaining ESL funds are to be used for "intensive English language programs for non-English-speaking students who are newly arrived in Australia." 320 An "eligible new arrival" is defined in the statute as a person from a country other than Australia whose first language is a language other than English and who arrived in Australia the previous year. ${ }^{321}$ The intensive instruction is separate from the regular education program and is designed to prepare children for entry into primary or secondary education at either a government or nongovernment school. ${ }^{322}$ The guidelines again suggest the variety of purposes for which funds might be used and state that a per capita grant of $\$ 833^{323}$ will be made for each eligible student enrolled in a program of intensive English language instruction. ${ }^{324}$

In the State of Western Australia, the ESL program consists of the newarrivals program for immigrants or refugees and a different ESL program in the regular schools. ${ }^{325}$ Every 3 months, the Department of Education for the State of Western Australia notifies the Commonwealth how many new arrivals they have who will be attending an Australian school for the first time. The $\$ 833$ per child received from the Commonwealth is the only funding for the ESL program. A child may spend from 3 to 6 months in the program before being placed in a regular school. For the newly arrived non-English speaker, there are four intensive centers in the State-two primary school and two secondary school age programs-located near where the immigrants enter the country or where they are likely to settle first. In the more rural areas, there are not enough such children to warrant a center. Thus immigrant children who come into the oil-producing, mining, or agricultural areas enter a regular school and are given only "withdrawal" assistance, consisting of ESL instruction away from the regular classroom for 30 minutes a day, 5 days a week. If there are fewer than six or eight such children in a school, the State provides only an advisory teacher from the capital, who visits the school from time to time to consult with regular teachers.

The intensive centers provide programs in three stages: (1) an intensive program in survival English-basic language skills children might need "on the street"; (2) a transition program in which they begin to learn the language of subjects they will be studying in school; and (3) a "withdrawal program" providing supplementary help to those who have recently entered the public schools. ${ }^{326}$

The teachers in the intensive centers are drawn from the best ESL teachers

320. Id. $\S 6.3$, at 39 .

321. States Grants (Schools Assistance) Act 1982, § 3(1), 1982 Austl. Acts 1745, 1751; GuideLINES, supra note $316, \S \S 6.17-6.20$, at 42-43.

322. States Grants (Schools Assistance) Act 1982, § 12(2)(b), 1982 Austl. Acts 1745, 1762.

323. All monetary figures are given in Australian dollars.

324. Compare with the Immigration and Nationality Act, 8 U.S.C. $\$ 1522$ (d) (1982), authorizing English language instruction in the schools for refugee children.

325. Interview with Dr. Harry Pearson, Director of Child Migrant Education and Multicultural Education, Department of Education, Western Australia (July 12, 1983) (memorandum on file with author).

326. Id. 
in the regular schools. ${ }^{327}$ There is, however, very little training for teachers of English as a Second Language, at least in Western Australia. What training there is consists of a short program of in-service training: 5 days in intensive study and then 5 additional Fridays. ${ }^{328}$

In New South Wales, there is pressure for bilingual education that could be termed language maintenance rather than transitional education. The major ethnic organizations pushing for a community languages program provided by the school system include Greek, Italian, Turkish, Arabic, and Yugoslav organizations. ${ }^{329}$ The Labor Party, which has only recently been elected to office, has apparently made promises that it would provide bilingual education where there were concentrations of ethnic groups. As a result, some recent observers have predicted that the issue of bilingual education will become a much more significant issue in Australia as the Labor Party attempts to deliver on its promise. ${ }^{330}$

2. Ethnic Schools Program. Funds for ethnic education programs under the statute are to be spent on joint government and nongovernment school programs administered by a nongovernmental authority. The ethnic education grants require only that the state ensure that the funds received for ethnic education will be paid to a nongovernmental school authority, that the nongovernmental school authority furnish the Commonwealth with a private accountant's certification that funds have been applied as intended, and, as is generally the case when monies are to be administered by a nongovernment school authority, that there be a formal agreement between the state and the nongovernment school authority.

The Commonwealth Minister of Education must designate a body as an approved ethnic schools authority before it can receive funds from the Commonwealth. Funds are approved only if it is shown that the program will be open to all, regardless of ethnic origin, and that no other financial assistance will be provided by the Commonwealth toward the program. The Guidelines state that the program is to "help maintain the languages of people from nonEnglish-speaking backgrounds." 331 Ethnic schools authorities are eligible for assistance under the Guidelines, if their programs are:

- designed to teach a community language (which may or may not be accompanied by cultural instruction) and where religious instruction does not form a predominant part of the program;

- open to students from any ethnic background . . . ;

- and not supported by other financial assistance provided by the Commonwealth towards any recurrent expenditure.

327. Id.

328. Id.

329. Interview with Dr. Douglas Swan, Director-General, and staff members, Department of Education, New South Wales (July 22, 1983) (memorandum on file with author). Dr. Swan noted that he was stressing "organizations," not parents.

330. Interview with members of the Commonwealth Schools Commission (July 8, 1983) (memorandum on file with author).

331. Guidelines, supra note 316 , at 47. 
Funding will not be available to ethnic schools which are regarded as serving political instruction purposes. ${ }^{332}$

In the State of Western Australia, ethnic schools meet after school or on Saturday mornings in government school buildings. The Commonwealth provides $\$ 30$ per child per year for a 2 -hour language and culture program. The particular ethnic community involved provides the teachers. Children who go to the ethnic schools also attend the regular schools during the regular school day.

\section{Multicultural Programs. Multicultural education is defined as:}

education . . that is provided for students attending government or non-government schools and that is designed to take account of the culture of peoples of the Aboriginal race of Australia or of peoples who have migrated to Australia, including . . . education that is provided by way of instruction in languages (other than the English language) spoken by those peoples. ${ }^{333}$

The Commonwealth Schools Commission funds the multicultural program in its entirety. Funds may be spent on a variety of activities, excluding the teaching of English as a Second Language. ${ }^{334}$ The eastern states purportedly have better programs of multicultural education because of the larger proportion of immigrants. The nature and quality of the programs vary considerably from state to state as there are no conditions, other than fiscal reporting, attached to the federal funding. The Western Australia Department of Education staff members assigned to develop these programs feel they are struggling in an environment in which the programs are not deemed very important. There are limited resources and limited support. Multicultural education also tends to be limited to European cultures; Asian and Aboriginal cultures are generally excluded. In parts of Western Australia distant from Perth, there is even less interest in multicultural education. Several school officials have indicated that the money is used in non-productive ways. Teachers are not really interested in taking on yet another program. Moreover, no great pressure for change appears to be coming from parent or community groups. ${ }^{335}$

It is apparent from the foregoing that, perhaps because there are no particular requirements imposed by the federal government as a condition for receipt of grants, the extent of programs for language minority children may be greater in some states than in others.

332. Id. at 48. Funds can only be used for "educational purposes of a recurrent nature" and nol for capital expenses, although use of federal funds for the rental of premises is permitted. Id. at 49

333. States Grants (Schools Assistance) Act 1982, § 3(1), 1982 Austl. Acts 1745, 1752.

334. Guidelines, supra note 316 , at 44.

335. Interviews with Dr. Harry Pearson, Director of Child Migrant Education and Multicultura Education, Department of Education, Western Australia (July 12, 1983); with staff members, Mul. ticultural Affairs, Department of Education, Western Australia (June 29, 1983); and with Willian McKenzie, Educational Officer, Goldfield Region District, Kalgoorlie, Western Australia (July 15 1983) (memoranda on file with author). 


\section{B. Programs for the Handicapped}

As is well known, section 504 of the Rehabilitation Act of $1973,{ }^{396}$ with its comprehensive set of regulations, imposes upon school authorities in the United States stringent requirements regarding educational opportunities for the handicapped. In addition, the Education for All Handicapped Children Act (EAHCA) ${ }^{337}$ is an extremely prescriptive grant-in-aid statute; many of the conditions look to the provision of procedural safeguards rather than substantive requirements. Under the EAHCA, a handicapped child is entitled to a "free appropriate public education" which includes those "related services" necessary to enable the handicapped child to benefit from special education. ${ }^{338}$ States and school districts are required to identify and locate all unserved handicapped children. ${ }^{339}$ Special education and related services are to be provided in accordance with an individualized education program (IEP). ${ }^{340}$

An "appropriate" education is one that takes place in the least restrictive educational setting. ${ }^{341}$ If the regular educational setting is inappropriate for academic subjects, handicapped students must at least participate with nonhandicapped students in nonacademic and extracurricular activities. Congress has thus mandated "mainstreaming" or "integration" (the term more frequently used in Australia) of the handicapped. The burden is put on the educational system to show that the child could not be educated satisfactorily in a regular classroom; that is, Congress has imposed an affirmative duty on state and local authorities to provide special aids, services and other resources to enable handicapped children to overcome the barriers to an equal educational opportunity imposed by their handicap. There are also extensive procedural requirements and safeguards for handicapped children and their parents. ${ }^{342}$ To meet the requirements of the federal statute, states and school districts must make substantial expenditures from their own resources, as the federal funds do not begin to cover the needs of the handicapped.

By contrast, the federal program for the handicapped in Australia is quite limited. For school-age children, special education is defined in the States Grants (Schools Assistance) Act 1982 as "education under special programs designed specifically for handicapped children that is provided in classes conducted at schools, or in classes conducted at centres other than schools . . . " 343 Financial aid is provided to the states "for the purpose of meeting recurrent expenditures . . . in connection with special education provided at

336. 29 U.S.C. $\& 794$ (1982).

337. 20 U.S.C. $\$ \S 1400-1461$ (1982).

338. Id. $\$ \S 1400(\mathrm{c}), 1401(17)$.

339. Id. \$ $1414(\mathrm{a})(1)(\mathrm{A})$.

340. Id. $\$ 1414(\mathrm{a})(5)$.

341. "A recipient shall place a handicapped person in the regular educational environment . . unless it is demonstrated by the recipient that the education of the person in the regular environment with the use of supplementary aids and services cannot be achieved satisfactorily." 34 C.F.R. $\S 104.34$ (a) (1984).

342. 20 U.S.C. § 1415 (1982).

343. States Grants (Schools Assistance) Act 1982, § 3(1), 1982 Austl. Acts 1745, 1755. 
or in connection with government schools or government centres in the State." 344 Funds also go to nongovernment schools for expenditures in connection with special education. ${ }^{345}$

The states must ensure that the amount of the grant they receive is spent for this purpose, and that a portion of the grant is "applied in connection with integration activities conducted at government schools in the State or places of education approved by the Minister . . ."346 For example, in the 1982 Act, Western Australia received $\$ 103,000$ for "government integration activities" out of a total of $\$ 1,876,000$ for special education. ${ }^{347}$ "Integration activities" are defined as: "activities the purpose of which is to integrate handicapped children into schools, or other places of education approved by the Minister . . . , at which education is provided for children other than handicapped children . . . "348 Fiscal reporting requirements include certification by an authorized person that the funds have been spent for the designated purpose and a statement indicating for what the money was spent. ${ }^{349}$

In Australia, there are no extensive conditions attached to the receipt of funds for special education comparable to those in the EAHCA. "Integration" is not prescribed as "mainstreaming" is in the United States. Nor are there the other kinds of requirements seen in the EAHCA, such as the requirement to provide supplementary aids or services for the integrated handicapped students. ${ }^{350}$ In some areas in the State of Western Australia, for example, there are special education classes only for the primary grades. Therefore, once students complete the primary grades, they are "integrated" into the regular classes in the secondary school without any supplementary aids or services. ${ }^{351}$

The Schools Commission's Guidelines for special education grants provide: "[F]unds are allocated according to priorities determined by the States in meeting the special needs of handicapped children. These needs will vary from school to school according to the type of handicap being catered for." 352 With regard to integration of the handicapped, in contrast to the stringent requirements of the EAHCA, the Guidelines note that "there are differences in the extent to which integration has been achieved and . . variations in State and Territory policies concerning the ways in which it should be undertaken." 353 The Guidelines also give examples of the use to which integration

344. Id. $\S 15(2), 1982$ Austl. Acts at 1763.

345. Id. § 32(2), 1982 Austl. Acts at 1782.

346. Id. § 15(2), 1982 Austl. Acts at 1763 .

347. Id. sched. 4, 1982 Austl. Acts at 1800 .

348. Id. $\S 3(1), 1982$ Austl. Acts at 1752 .

349. Id. § 17, 1982 Austl. Acts at 1765 .

350. 20 U.S.C. $\$ 1414$ (a)(1)(C)(iv) (1982).

351. Interview with Derrick Tomlinson, Director of the National Centre for Research on Rural

Education, University of Western Australia (June 28, 1983) (memorandum on file with author).

352. Guidelines, supra note 316 , at 22.

353. Id. at 26. The Commission, however, recommends that funds be applied in accordance with the following priorities:

- The movement of handicapped children from special to regular schools; 
funds may be put, which include in-service training of teachers, equipment, development of curricular materials, speech therapy, excursions, teacher salaries, transportation, and minor building projects such as installation of handrails and ramps and widening of doorways. ${ }^{354}$

Some of the members of the Commonwealth Schools Commission have expressed concern about what is happening to the funds for the handicapped because there are no meaningful conditions and no mechanism for enforcement of the Guidelines. Many schools use the money to buy equipment, but there is a dearth of programs, particularly programs for the mentally handicapped. It has also been suggested that, because of the strong teachers' union in Australia, pressures for integration of the handicapped might lead to teacher demands for smaller class sizes. Consequently, the issue of integration has received little attention. ${ }^{355}$

Although requirements at the federal level are limited, a number of the states have legislation for the handicapped. Under Western Australia's statute, if the parents disagree with the placement of the child, an assessment panel can be convened. The panel makes recommendations to the Minister, and once the Minister has issued a "direction," the burden shifts to the parent to show that the Minister's direction is incorrect. If the parents do not agree with the "Minister's direction," they have 30 days within which to go to the children's court. ${ }^{356}$ The state's guideline with regard to integration is "the maximum useful association in the best interests of all children." 357

The Commonwealth Schools Commission's funds are primarily spent for salaries and special equipment in Western Australia. ${ }^{358}$ There is no requirement at either the state or the Commonwealth level that the school system identify unserved and underserved handicapped children. ${ }^{359}$

In one region of Western Australia outside of the capital city area, ${ }^{360}$ even fewer services are provided to the handicapped than in Perth. The decision whether to place a child in a special class within a regular school rather than in a special school is made by the educational psychologist for the district, often

- the provision of services to enable isolated handicapped children to attend neighborhood schools;

- facilitating enrollment into regular primary schools of handicapped children who are beginning their formal schooling;

- the funding of activities to assist in the education of handicapped children already fully or partially integrated into regular schools; and

Id. at 26-27.

facilitating enrollment into regular pre-schools of handicapped children below school age.

354. Id. at $27-28$.

355. Interview with members of the Commonwealth Schools Commission (July 8, 1983) (memorandum on file with author).

356. Interview with Dr. Robert Weiland, Superintendent for Special Education, Department of Education, Western Australia (July 12, 1983) (memorandum on file with author).

357. Compare this with the EAHCA's requirement of the "least restrictive environment." 20

U.S.C. $\$ 1418(\mathrm{f})(2)(\mathrm{E})(1982)$.

358. Interview with Dr. Robert Weiland, supra note 356. 339.

359. Id. Compare this with 20 U.S.C. \& 1414 (a)(1)(A) (1982). See supra text accompanying note

360. Kalgoorlie, Western Australia is a mining town of about 20,000 . 
based on whether the child can follow instructions, sit still at a desk, and so forth. In other words, children are sent by the educational psychologist to a special education class in the regular school if they have "appropriate adaptive behavior." There they get instruction, but at a reduced level. Others are sent to special schools for the handicapped. In addition, Aboriginal children who come into the school system at older ages (nine or ten) without any prior education are put in special education classes. Since these children will not be up to their age level in math or reading, there is no place to put them other than in a special education class. ${ }^{361}$

If the regular school is one which schedules "softer" courses such as arts and crafts or music in the afternoon, some of the special students may join classes of regular students. However, children who cannot "adjust to the regular classroom" or who "aren't accepted" in the regular classroom remain separate even for the "softer" courses. In this district, when children are "integrated" into the "softer" classes, the regular teacher is given no special assistance or guidance. There are no teacher aides, supplementary services, or other resources. ${ }^{362}$ Indeed, outside the capital city, at least, special education classes are often assigned to novice or inexperienced teachers. There is no significant special training or degree in special education in Western Australia. ${ }^{363}$

It is really the school principals who decide whether there will be special education classes in their schools and how they are to be operated. If they do not want the handicapped to mingle with other children, no mingling will occur. Under the handicapped law in Western Australia, however, a principal cannot place a child in a special education class without an assessment by the educational psychologist or by the guidance counselor, and an assessment cannot be undertaken without the written permission of the parent. It is also up to individual teachers to determine whether the children will interact on the playground. Only if the school is organized conveniently, with academic subjects in the morning and arts and crafts or music in the afternoon, can there be integration in nonacademic subjects as well. ${ }^{364}$

In New South Wales, there is no state legislation for the handicapped, although such legislation was being proposed in 1983. Under the then existing system parents could reject the placement of their child in a separate institution and demand that the child be integrated, but it was still up to school principals to decide whether a school would admit the child or not. A parent could appeal the principal's decision to the Director-General of the State Education Department. Under the proposed legislation, an independent panel would be established for the appeal. ${ }^{365}$

361. Interviews with school officials in the Goldfield Region District, Western Australia (which includes Kalgoorlie and several smaller towns) (July 15, 1983) (memoranda on file with author).

362. Id.

363. Id.; see also interview with Dr. Robert Weiland, supra note 356.

364. Interviews with school officials in the Goldfield Region District, supra note 361.

365. Interview with Dr. Douglas Swan, supra note 329. 


\section{Programs for the Economically Disadvantaged}

The Australian Disadvantaged Schools Program is somewhat comparable in purpose to Title I of the Elementary and Secondary Education Act in the United States, although the statutes operate very differently. ${ }^{366}$ Conditions for receipt of Title I funding are extensive, occupying many pages of the statute. For example, in order to receive funds, a local educational agency (LEA) must use the funds "in school attendance areas having high concentrations of children from low-income families," and if the funds are insufficient to provide programs for all educationally deprived children in the eligible areas, the LEA must rank its school attendance areas from highest to lowest, in accordance with the degree of concentration of children from low-income families. ${ }^{367}$ Funds are available only if an LEA makes "an assessment of educational need each year." 368 This assessment must "identify [the] educationally deprived children in the eligible attendance areas and . . . select those educationally deprived children who have the greatest need for special assistance"; identify the instructional areas for the program; and determine the "special educational needs" of the children who will participate in the program. ${ }^{369}$ The funds received by an LEA may only be used for programs "which are of sufficient size, scope, and quality to give reasonable promise of substantial progress toward meeting the special educational needs of the children being served. ${ }^{370}$

LEA's may receive funds only if they adopt effective procedures for evaluating the effectiveness of the programs "in meeting the special educational needs of the educationally deprived children." 371 LEA's may not receive funds unless teachers, school boards, and parents of children participating in the programs are involved in the planning of the programs. ${ }^{372}$ There must be an advisory council for the entire school district and the composition of that advisory council is specified in the statute. It must include members elected by the school advisory councils, representatives of children and schools eligible for Title I programs but not participating in those programs (these rep-

366. Pub. L. No. 89-10, 79 Stat. 27 (1965), later amended by Act of Nov. 1, 1978, Pub. L. No. 95561, 92 Stat. 2143, 2152-201. This Act was repealed in 1981 and has now become chapter I of the Education Consolidation and Improvement Act, Pub. L. No. 97-35, tit. V, subtit. D, 95 Stat. 463 (1981) (codified in scattered sections of 20 U.S.C.), which is comparable in scope and character. Title I's preamble sets forth its purpose:

In recognition of the special educational needs of children of low-income families and the impact that concentrations of low-income families have on the ability of local educational agencies to support adequate educational programs, the Congress hereby declares it to be the policy of the United States to provide financial assistance . . . to local educational agencies serving areas with concentrations of children from low-income families to expand and improve their educational programs by various means (including pre-school programs) which contribute particularly to meeting the special educational needs of educationally deprived children.

20 U.S.C. $\S 2701$ (1982); see also id. $\$ 3801$.

367. Id. $\$ 2732(\mathrm{a})(1)$.

368. Id. $\$ 2734(\mathrm{~b})$.

369. Id.

370. Id. $\$ 2734$ (d). Ordinarily, no project may be less than $\$ 2,500$. Id.

371. Id. \& $2734(\mathrm{~g})(\mathrm{l})$.

372. Id. \& 2734 (i)-(j). 
resentatives must be elected by the parents in such areas), and a majority of its members must be parents of children to be served by Title I projects. ${ }^{373}$ In addition, each project area or school must also have an advisory council, and a majority of its members also must be parents of children to be served by the programs. Members must be elected by the parents in the project area. ${ }^{\mathbf{3 7 4}}$ School districts are required to provide a program for training the members of advisory councils. ${ }^{375}$

With regard to fiscal requirements, LEA's are required to maintain their level of spending from state and local funds in order to receive federal funds under Title I ("maintenance of effort"); 376 funds may only be used to cover those program costs which exceed the average per pupil expenditure for pupils in the LEA ("excess costs");"377 and funds may be used only "to supplement and, to the extent practical, increase the level of funds that would, in the absence of such Federal funds, be made available from regular non-Federal sources . . . , and in no case may such funds be so used as to supplant such funds from such non-Federal sources."'378 There are also "comparability requirements": an LEA may receive funds "only if State and local funds will be used . . . to provide services in project areas which, taken as a whole, are at least comparable to services being provided in areas in such district which are not receiving [Title I] funds." 379 Detailed recordkeeping is required by each school district and extensive reports are required to be filed annually. ${ }^{380}$

In contrast, the requirements for Australia's Disadvantaged Schools Program are quite minimal. In the States Grants (Schools Assistance) Act 1982, a disadvantaged school is defined as a school "that should, in the opinion of the State Education Minister, be treated as a disadvantaged school."381 In the States Grants (Schools) Act 1973, a disadvantaged school was defined more precisely as a school

(a) the students at which, or a substantial portion of the students at which, are members of a community which, for social, economic, ethnic, geographic, cultural, lingual or any similar reason, has a lower than average ability to take advantage of educational facilities; and (b) which requires special facilities (whether in the form of buildings, equipment, teaching staff or in some other form) for the purpose of enabling the school to provide adequate educational opportunities for students at the school. ${ }^{382}$

Disadvantaged schools can be government or nongovernment schools. The only statutory conditions for receipt of the funds are the usual fiscal reporting requirements. ${ }^{383}$ In the Schools Commission's Guidelines, "school communities," as a condition of funding, "are required to review their objec-

373. Id. $\S 2735$.

374. Id. \$ $2735(\mathrm{a})$.

375. Id. $\$ 2735(\mathrm{~d})$.

376. Id. $\$ 2736(\mathrm{a})$.

377. Id. $\S 2736(\mathrm{~b})$.

378. Id. $\$ 2736(\mathrm{c})$.

379. Id. $\$ 2736(\mathrm{e})$.

380. Id. \& $2737(\mathrm{a})-(\mathrm{b})$.

381. States Grants (Schools Assistance) Act 1982, § 3(1), 1982 Austl. Acts 1745, 1751.

382. States Grants (Schools) Act 1973, \& 3(1), 1973 Austl. Acts 1407, 1411-12.

383. See supra text accompanying note 98 . 
tives and operations, to draw up proposals designed to improve learning outcomes, to relate the curriculum more closely to the life experiences of the children enrolled, and to bring about a closer association between parents and the school."384 Almost anything can be supported under the rubric of a "Disadvantaged Schools Program": curriculum innovation, basic skills programs, or programs for promoting interaction with the community. ${ }^{385}$ Most programs, however, are concerned with promoting the involvement of the community in the school. Funds are supposed to be allocated in response to proposals formulated at the school level. Although the Commission Guidelines state that parents and teachers should participate in the formulation of these proposals, ${ }^{386}$ such participation is not required; even if it were, there is no mechanism for enforcing such a requirement. State education ministers are responsible for determining which schools are to be declared disadvantaged schools.

Although the federal grants are supposed to supplement or "top up" what the states are providing through their general funds, there is concern that there may be a good deal of substitution rather than supplementation, because there are no requirements such as the "maintainance of effort" and "supplement, not supplant" provisions of Title I. ${ }^{387}$ Indeed, although the Disadvantaged Schools Program has been in existence for 10 years, there is no comprehensive and systematic way of determining what the impact of the program has been. The Schools Commission itself has undertaken no evaluations and there has been no other objective evaluation.

In many states the Disadvantaged Schools Program operates through a joint committee for disadvantaged schools which has representatives from the Catholic Education Commission, the independent schools, and the State Department of Education. ${ }^{\mathbf{3 8 8}}$ These committees are supposed to follow the Guidelines, but there is currently no mechanism for the Commonwealth to determine whether they are being followed. The Disadvantaged Schools Program differs from Title I in that it provides aid for disadvantaged schools rather than disadvantaged children; there are, accordingly, some schools that have severely disadvantaged children, but not enough to meet the criteria for receiving funds. Other schools may have a sizeable minority of non-disadvantaged children, yet program aid is used to benefit the entire school. A second problem, from the perspective of some state administrators, is that in many cases funds are not spent usefully, often going for equipment. ${ }^{389}$

In New South Wales, there are now 418 disadvantaged schools, most of which have been "on the list" for at least 3 years, and many for much longer, even though the character of the student population may have changed in the

384. Guidelines, supra note 316, at 17 .

385. Id. at 17-18.

386. Id. at 18 .

387. 20 U.S.C. $\$ 2736$ (a)-(c), (e) (1982); see supra text accompanying notes 376-79.

388. Interview with Dr. Robert Vickery, Director-General, Department of Education, Western Australia, and other State Department officials (July 12, 1983) (memorandum on file with author). 389. Id. 
meantime. The Disadvantaged Schools Program does not provide much money. There are only about 130,000 children attending the disadvantaged schools in New South Wales, which receives about $\$ 70$ per capita from the Commonwealth to support the program. ${ }^{390}$

State Education Department officials in New South Wales consider that the impact of the Disadvantaged Schools Program has been on the general system. For example, the community is supposed to be involved in developing funding proposals. Therefore, many schools, whether disadvantaged or not, have now established in-school planning committees. Although some schools there have misused funds for equipment, ${ }^{391}$ most of the money received probably goes for instruction. One concern, however, is that the high level of community involvement might protect the program even if it is not as effective as other possible programs would be.

\section{Summary of Australia's Grant Programs for Special Pupil Populations}

As the foregoing analysis has indicated, the Commonwealth has not conditioned any of its specific purpose grants on the establishment of significant substantive or programmatic requirements or procedural safeguards for the target pupil populations. Thus Australia's current approach has been very different from that taken by the federal government in the United States.

One problem with the federal role in education as it has developed in the United States is the increasing number of federal requirements that have been enacted in the last 20 years, beginning with Title VI of the Civil Rights Act of $1964,{ }^{392}$ followed by Title I, and further complicated by various statutes and regulations prohibiting discrimination based on gender, handicap, and national origin. In addition, federal aid for the handicapped, and for students with limited English proficiency, has been extensively conditioned on both procedural and substantive requirements.

It has been difficult for states, school districts, and schools to adjust to this proliferation of programs and requirements. Each new federal program or mandate has been established and administered separately from previous programs and requirements. School districts and states, therefore, tend to create separate administrative structures for the various programs. It is at the school level, however, that the combined effects of these requirements are felt. The reporting requirements are extensive and require a good deal of paperwork for both teachers and administrators. In the case of teachers, one of the principal concerns is that the considerable administrative burdens may take time away from actual classroom instruction. The fiscal reporting requirements have also encouraged the use of "pull out" programs ("withdrawal" programs in Australia), removing children from regular classrooms for special treatment.

390. Interview with Dr. Douglas Swan, supra note 329.

391. One example given was of a school which used program funds to purchase six tables for table tennis. Id.

392. 42 U.S.C. $\S \S 2000 d$ to $2000 d-4$ (1982). 
With so many proliferating categorical programs, schools have often taken an uncoordinated approach to the child who falls into more than one category. The educational problems of such children are compartmentalized in response to federal accounting requirements rather than being classified according to the children's educational needs. Thus the tendency has been to organize the delivery of educational services to special pupil populations in accordance with federal funding categories rather than along functional lines.

Another problem is that many requirements, unfunded mandates as well as conditions to grants-in-aid, must be financed from state and local revenues at a time when school districts have come under increasingly severe financial restraints. Moreover, the enforcement of civil rights requirements has been complicated by the fact that the principal remedy for noncompliance is the termination of federal funds, a draconian measure that the federal government is reluctant to use because it punishes the very children that the laws are designed to help.

The system in Australia avoids many of these problems either by taking a school-based approach for programs such as the Disadvantaged Schools Program, or by not imposing burdensome requirements that create undue amounts of paperwork or limit the ability to adapt to the needs of a particular community. There are, however, other problems with the Australian system which have been pointed out previously.

There are significant differences between Title I programs and the Disadvantaged Schools Program as they are actually implemented. Largely as a result of detailed federal regulation, Title I programs generally take the form of supplementary instruction in the basic skills. The Disadvantaged Schools Program in Australia is much broader and thus permits a greater variety of programs not necessarily addressed to cognitive skills alone. Also, since the program is school-based, rather than confined to specific targeted students, the "pull out" problem is avoided. The difference in the size of the programs - 14,000 school districts (and multiple schools within many of those districts) receiving Title I funds, in contrast to about 1,000 schools in the Disadvantaged Schools Program - may explain, in part, the need for extensive regulation in Title I programs.

Owing to disparities in per pupil expenditures among school districts, Title I funds are not always a means of getting more than average resources to disadvantaged pupils. In many cases, particularly in rural and impoverished urban districts, Title I funds help bring resources up toward the average in low-spending districts. ${ }^{393}$ By contrast, the Disadvantaged Schools Program does provide greater than average resources to the schools selected. The funds are so minimal for this program, however,-amounting to only about $\$ 50$ per pupil nationally-that they hardly constitute a significant increase over regular per pupil expenditures. Using these funds to supplement the

393. On the other hand, the Title I program has done much to eliminate intradistrict disparities in state and local funding. Thus as between Title I and non-Title I schools within a school district, the funds can be a significant increment. 
teaching of basic skills would accomplish little. A program which fosters school-based experimentation and community involvement with the school may be better suited to the limited nature of the funding and the limited number of schools participating. Thus the U.S. program seeks to attack directly low achievement in specific pupils; the Australian program seeks to improve schooling in schools where there has been the least pupil success.

The Australian program neither identifies the problem nor specifies an approach to addressing it. There is no way to measure the effectiveness of programs that are developed in individual schools, or to disseminate knowledge about what works and what does not. Thus it is unclear whether the Disadvantaged Schools Program has had any significant impact on the target children, and whether the funds are being effectively used to address academic and related needs.

Programs for language minority children in Australia have primarily been directed toward new arrivals (children whose language is other than English and who have not yet entered an Australian school), with intensive instruction to prepare them to enter a regular school. The Commonwealth cannot ensure that a state does much more than that. ESL training for teachers is rudimentary, and "withdrawal" programs are for minimal periods during the school week. Nothing is done for second or third generation children with limited English proficiency, although such children exist in Australia as well as in the United States. Affirmative language assistance programs are much better developed in the United States and apply to a wider group of children than in Australia.

In the area of aid to the handicapped, the situation in Australia appears to be similar to that in the United States prior to the first major lawsuit establishing the rights of the handicapped, Pennsylvania Association for Retarded Children v. Pennsylvania. ${ }^{394}$ In Australia, neither parents nor the children themselves enjoy significant procedural or substantive guarantees of an equal educational opportunity for handicapped children. Individual school principals retain a good deal of autonomy in this area. In the United States, the EAHCA, without dictating educational content, establishes the right to a free appropriate public education guaranteed through procedural safeguards, permitting parents to participate in developing the child's individualized education plan and in determining appropriate placement for the child. In Australia, by contrast, no state except Western Australia ${ }^{395}$ has passed legislation providing for parental involvement in decisions regarding the education and placement of a handicapped child. No such requirements are attached to the receipt of Commonwealth funds, and parents do not enjoy a right of appeal.

394. 343 F. Supp. 279 (E.D. Pa. 1972) (consent decree); see also Mills v. Board of Educ., 348 F. Supp. 866 (D.D.C. 1972).

395. Western Australian legislation gives parents a right to participate in a planning conference and a right of appeal from decisions of the Minister, Education Act 1928-1981, 19 Geo. 5, no. xxxiii, $\S 20 \mathrm{E}, 5 \mathrm{~W}$. AUSTL. REPR. ACTs 1, 33 (1982), but this has not had a significant impact on parental involvement in placement decisions. See supra text accompanying note 356. 


\section{VI \\ Conclusion}

The High Court decisions in Koowarta v. Bjelke-Petersen ${ }^{396}$ and the Tasmanian Dam Case ${ }^{397}$ indicate that the Australian Parliament, using its external affairs power, could enact federal legislation guaranteeing equal educational opportunity for various special pupil populations. Existing international covenants and agreements on human rights provide a sufficient nexus for such domestic legislation. In addition, the Parliament has broad power under section 96 of the Australian constitution to condition its specific purpose grants for education so as to protect the interests of children with special needs, much in the same way as the U.S. Congress has done in Title I of the Elementary and Secondary Education Act, ${ }^{398}$ the EAHCA, ${ }^{399}$ and the Bilingual Education Act. ${ }^{400}$

Although the Parliament would seem to have the constitutional authority to enact civil rights mandates in the area of education and to condition its aid to education programs on similar requirements, the question is whether Australia's traditions and political/legal culture will permit this authority to be exercised. Australia's educational system is basically paternalistic: the power of educational decisionmaking is entrusted to the professional. The political/legal culture of the United States, fostered by the Bill of Rights and its tradition of protecting the individual, makes parents more ready to assert their rights against the professional and courts more ready to enforce those rights than is evident in Australia.

In light of the strong Australian preference for "states' rights" rather than a strong national government, combined with a tradition of deferring to professionals, ${ }^{401}$ it would not be suprising if there is, in the future, little change in

396. 39 Austl. L.R. 417 (1982); see supra notes 125-60 and accompanying text.

397. Commonwealth v. Tasmania, 46 Austl. L.R. 625 (1983); see supra notes 161 -2 13 and accompanying text.

398. Pub. L. No. 89-10, tit. I, 79 Stat. 27, 27-36 (1965) (codified as amended in scattered sections of 20 U.S.C.); see supra note 366.

399. 20 U.S.C. $\S \S 1400-1461$ (1982); see supra text accompanying notes 337-42.

400. Id. \$\$ 3221-3261; see supra text accompanying notes 306-15.

401. Despite the much less intrusive nature of the federal programs in Australia, the tensions between the state departments of education and the Commonwealth are reminiscent of those in the United States. Consider the following:

The role of the Director-General of Education as an instrument of State Government policy is complicated by the increasing prevalence of education policy dictates from the Commonwealth Government. The increasing use of specific purpose grants under Section 96 of the Commonwealth Constitution, has enabled the Commonwealth Government to impose its own educational priorities by making grants available for special purposes such as Aboriginal education, multicultural education, community involvement in schools, choice and diversity in schools, professional development, school-based curriculum development, transition education, and English as a second language. These priorities may or may not conform with the priorities of State Governments which consider themselves more able than a national government to accurately assess the needs of students....

The Commonwealth's priorities . . . have been pursued by . . . the Schools Commission . . . . Inevitably with the extension of the national educational bureaucracy, questions of power and personality impinged on the deeper philosophical and educational issues . . . . [T] he determination of specific priorities is the prerogative of State Governments . . . . 
the status quo. ${ }^{402}$ It seems likely that some civil rights protections related to education will be introduced by the Labor Government, but they are unlikely to contain the kinds of sanctions, or to be implemented with the kind of detailed regulations, found in the United States. It also seems unlikely that the Government will use its section 96 power to attach extensive conditions on its federal aid to education.

In sum, there is constitutional authority for significant changes in the current system, but the political/legal culture of Australia will inhibit such changes, at least in the near future. The seeds have been planted, however, and perhaps a model may yet develop that includes some of the "rights" focus of the U.S. legislation, while retaining some of the flexibility and cooperative nature of the current Australian approach.

Vickery, The Practising Administrator: Dilemmas and Strategies of a State Department of Education, (July 1983) (unpublished paper).

402. But see Buss, Special Education in England and Wales, Law \& ConTemp. Probs., Winter 1985, at 119 (indicating that Great Britain has begun to alter the status quo with regard to the rights of handicapped children to an equal educational opportunity). 
